\title{
VI./XII. Asırda Bir Abbâsî Veziri: Adudüddîn İbnü’l-Müslime’nin Siyasî ve İdarî Etkinliği*
}

\author{
Halil İbrahim Hançabay**
}

\begin{abstract}
$\ddot{\mathbf{O} z}$
Abbâsî bürokrasisinde uzun yıllar görev yapmış bir aileye mensup olan Adudüddîn İbnü'l-Müslime babası İzzüddîn Abdullah b. Hibetullah'n vefatyla birlikte onun yerine üstâdârlığa tayin edilmiştir. Bundan sonraki süreçte etkinliği giderek artan Üstâdâr İbnü'l-Müslime, Vezir İbn Hübeyre'nin zehirlenerek aniden vefat etmesiyle bu makama atanması muhtemel en güçlü aday olarak öne çıkmışır. Ancak Halife Müstencid, Adudüddîn İbnü'l-Müslime'nin yerine Bağdat'taki siyasî çevrelerle doğrudan bir irtibatı bulunmayan Vâsıt nâzırı (idareci/müfettiş) Ebû Ca'fer Ahmed b. el-Beledî’yi vezirliğge tayin etmiştir. İdarî açıdan nüfuzunun engellenmek istendiğini anlayan İbnü'l-Müslime ise dönemin etkili şahsiyetlerinden Emîr Kutbüddîn Kaymâz'la ittifak kurmuş ve birlikte Müstencid'i bertaraf ederek Müstazî̀yi tahta çıkarmışlardır. Müstazî de ilk icraat olarak İbnü’l-Müslime'yi vezirliğe, Emîr Kaymâz’ı ordu komutanlığına, İbnü'l-Müslime'nin oğlu Kemâlüddîn’i üstâdârlığa tayin etmiştir. Bu çalı̧̧ma İ̉nü'l-Müslime ailesinin Abbâsî idarî tarihindeki en etkili şahsiyetlerinden olan Adudüddîn İbnü'l-Müslime'nin bir üstâdâr ve vezir olarak siyasî ve idarî hadiseler üzerindeki rolünü incelemeyi hedeflemektedir. Bunun için öncelikle Adudüddîn'in ailesi, yetişmesi, üstâdârlık yaptığı dönemde Halife Müstencid ve sabık vezir İbnü’lBeledî ile ilişkileri, ayrıca Vezir İbn Hübeyre'nin zehirlenmesinde herhangi bir etkisinin olup olmadığ̣ meselesi üzerinde durulmuştur. Ardından Müstencid'in öldürülmesi ve Müstazînin halife olmasındaki rolü, vezirliğe tayin edilmesi ve Emîr Kaymâz’la girdiği iktidar mücadelesi ele alınmıştır. Ayrıca konu bütünlüğünü sağlamak amacıyla,
\end{abstract}

* Makale hakkındaki tenkit ve tekliflerinden dolayı Doç. Dr. Saim Yılmaz, Arş. Gör. Muhammet Enes Midilli ve derginin anonim iki hakemine, ayrıca İbnü'l-Müslime ailesinin soy ağacinın hazırlanma aşamasındaki yardımlarından dolayı İrfan Savran'a teşekkür ederim. Kuşkusuz makalenin tüm sorumluluğu bana aittir.

** Doç. Dr., İstanbul Üniversitesi, İlahiyat Fakültesi, İslâm Tarihi ve Sanatları Bölümü, İstanbul/ TÜRKIYE, halilhancabay@istanbul.edu.tr ORCID: 0000-0002-0387-0824 DOI: 10.37879/belleten.2021.423

Makale Gönderim Tarihi: 12.02.2020 - Makale Kabul Tarihi: 21.12.2020

Belleten, Ağustos 2021, Cilt: 85/Sayı: 303; 423-461 
Adudüddîn İbnü’l-Müslime'nin çevresindeki şahısların birbiriyle ilişkilerine de işaret edilmiştir. Bu anlamda üstlendiği bürokratik görev sebebiyle dönemin nüfuz sahibi bir diğer şahsiyeti olan Sâhibülmahzen İbnü'l-Attâr'la Emîr Kaymâz arasındaki mücadeleye özellikle değinilmiştir. Son olarak İbnü'l-Müslime’nin Halife Müstazî ile arasının açılması ve öldürülmesi hakkında bilgi verilmiştir..

Anahtar Kelimeler: Abbâsîler, Bağdat, Vezirlik, Üstâdârlı, Adudüddîn İbnü’lMüslime.

\title{
An Abbāsīd Vizier in $6^{\text {th }} / 12^{\text {th }}$ Century: \\ The Political and Administrative Influence of Adūd al-Dīn Ibn al- Muslima
}

\begin{abstract}
Adūd al-Dīn Ibn al-Muslima belonged to a family that served in the Abbāsid bureaucracy for many years and was appointed as an ustādār to replace his father, Izz al-Dīn Abd Allāh ibn Hibat Allāh, after the latter's death. In the time afterwards, Ustādār Ibn al-Muslima steadily increased his influence and became prominent as the most likely candidate to be appointed vizier after Ibn Hubayra's sudden death by poisoning. But Caliph al-Mustanjid assigned Ibn al-Baladī, the financial inspector (nāzir) of Wāsit, who had no direct connection with the political circles of Baghād instead of Ibn al-Muslima, to the vizireate. Ibn al-Muslima realized that the caliph sought to curtail his political and administrative authority, and allied with Amir Qaymaz, one of the influential figures of the period, and they enthroned al-Mustadi by deposing al-Mustanjid. As his first action, al-Mustadī appointed Ibn al-Muslima to the vizierate; Amīr Qaymaz to the army command (amīr al-jaish); and Kamāl alDīn, the son of Adūd al-Dīn, to the office of ustādār. The aim of this article is to analyze the role of Adūd al-Dīn Ibn al-Muslima, one of the most influential members of Banū Muslima family, on political events as an ustādār and vizier in Abbāsid administrative history. First, the article will introduce the reader to Ibn al-Muslima's family, his relationship with Caliph al-Mustanjid and former vizier Abū Ca'far Ahmad ibn al-Baladī, and, also look at whether Ibn al-Muslima had a part in the poisoning of Vizer Ibn Hubayra. This will be followed by an assessment of his role in the killing of Caliph Mustanjid and al-Mustazī's becoming caliph, as well as his appointment to the vizireate, and his power struggle with Amīr Qaymaz. Additionally, to provide a complete picture of the issues at hand, this study tries to show the relationships that existed between the people who were around Ibn Muslima. Finally, Ibn Muslima's falling out with Caliph al-Mustazī and the former's death is addressed.
\end{abstract}

Keywords: Abbāsīds, Baghdad, vizierate, ustādār, Adūd al-Dīn Ibn al-Muslima 


\section{Giriş}

İslâm tarihinde ilk defa Abbâsîler'le birlikte ortaya çıkan vezirlik müessesesi devletin erken dönemlerinde nispeten basit bir görünüm arz ederken, II. (VIII) asrın başından itibaren daha teşekküllü bir yapı haline gelmeye başlamıştır. Türk kökenli askerî unsurların Vâsık-Billâh'ın (227-232/842-847) ölümünden sonra kumandan ve idareci sıfatıyla yönetimde söz sahibi olmaları vezirlerin nüfuzunu önemli ölçüde azaltmıştır. Ancak bu durum uzun sürmemiş, III. (IX.) yüzyllın sonlarından itibaren vezirler yeniden güç kazanmıştır. Bununla birlikte RâzîBillâh (322-329/934-940) tarafindan 324 (936) yllında resmî bir makam olarak emîrülümerâlı̆ıın ihdas edilmesi ve başına askerî ve idarî açıdan geniş yetkilerle İbnü'r-Râik'in getirilmesi vezirlerin bir kez daha otoritelerini kaybetmelerine neden olmuştur. Kısa bir süre sonra Irak Büveyhîleri'nin (334-447/9451055) Bağdat'a hakim olmasılyla vezirlik kurumu işlevini neredeyse tamamen yitirmiştir. Bu dönemde Büveyhî emîrlerinin kâtipleri vezirlerin yerini alırken, Abbâsî halifelerinin vezirleri ise kâtip sıfatıyla sadece halifelerin özel işlerini takip etmekle görevlendirilmiştir. Ancak Kâim-Biemrillâh'm (422-467/1031-1075) şahsî kâtibi Reîsürrüesâ İbnü'l-Müslime'yi ${ }^{1}$ (ö. 450/1059) vezirliğe tayin etmesi (8 Cemâziyelevvel 437/21 Kasım 1045) vezirlik kurumunun yeniden işlerlik kazanmasını sağlamıştı².

Abbâsîler döneminde halifeden sonraki en yetkili kişi konumunda bulunan vezirler idarî, hukukî, malî ve askerî sahalarla ilgili pek çok görevi yerine getirdikleri için bürokratik yapının başı kabul edilmişlerdir. Halifeyi korumak dışında memurları ve ziyaretçileri huzura çlkarmak ve resmî merasimleri düzenlemekle yükümlü olan hâcibler ise halifenin sırlarına vâkıf olmaları sebebiyle saray çevresinde önemli bir nüfuz elde etmişlerdir. Bu nüfuzları sayesinde zaman zaman vezir ve diğer görevlilerle rekabet edebilecek güce kavuşan hâcibler devlet kademesinde yapılan atamalarda etkin bir rol oynamışlardır. Ancak önceden halife sarayının idaresinden sorumlu olan ve "kahramâne" adı verilen kadın görevlinin yerine VI.

1 Makale boyunca "İbnü’l-Müslime” ibaresi yalnız başına kullanıldığında Adudüddîn’e işaret etmektedir.

2 Vezirlik kurumunun ortaya çıkışı ve Abbâsîler dönemindeki tarihî gelişimiyle ilgili geniş bilgi ve literatür için bk. Halil İbrahim Hançabay, Abbâsîler Döneminde Vezirlik (295-530/908-1136), Klasik Yayınları, İstanbul 2017, s. 38-58; Fatih Yahya Ayaz, "Vezir", İslam Ansiklopedisi, C 43, Türkiye Diyanet Vakfi, İstanbul 2013, s. 79-82.

3 Hâcib kelimesinin kökeni ve bir kurum olarak tarihî gelişimiyle ilgili geniş bilgi için bk. Hasan elBâşâ, el-Fünûnu'l-İslâmiyye ve'l-vezâif ale'l-âsâri'l-Arabiyye, I-III, Dârü'n-Nehdati'l-Arabiyye, Kahire 1965, G I, s. 380-403; Aydın Taneri, "Hâcib", İslâm Ansiklopedisi, G 14, Türkiye Diyanet Vakfi, İstanbul 1996, s. 508-511. 
(XII.) asrın başlarından itibaren üstâdâr olarak isimlendirilen erkek bir görevlinin tayin edilmesi hâciblerin saray içindeki etkinliklerini azaltmıştır. Halife sarayının gelir-gider işlerini yerine getirmek, hanedan ailesine ait gayr-i menkullerden elde edilen gelirlerin takibini yapmak, Kâbe'nin örtüsünün hazırlanmasına nezaret etmek gibi görevler üstlenen üstâdârlar bunların dışında hanedan ailesine ve özellikle halifeye yakınlıkları sayesinde devletin idaresiyle ilgili pek çok konuda önemli bir rol oynamıslardır. Öyle ki, üstâdârlar zaman zaman halife ve veziri nüfuzları altına alarak yüksek dereceli memurluklara yapılacak atamalarda ve üst düzey görevlilerin azledilmesinde en etkili kişi olabilmişlerdir. Ayrıca bu nüfuzlarının sonucu olarak üstâdârlar vezirliğe atanması muhtemel en güçlü şahıslar olarak öne çıkmışlardır.

Askerî birliklerin sevk ve idaresinden sorumlu olan ordu komutanları devletin silahlı gücünü emirleri altında bulundurmaları ve maaş karşılı̆̆ı veya mükâfat olarak kendilerine tevcih edilen iktâ arazilerinden kazandıkları yüksek gelirler sayesinde siyasî, askerî ve ekonomik açıdan ciddi bir güç haline gelmişlerdir.

Vezir, üstâdâr ve ordu komutanı dışında geç dönemlerde etkinliğini arttıran bir başka görevli, hazinenin gelir giderinden ve resmî harcamaların kontrolünden sorumlu olan sâhibülmahzendir. Her ne kadar sâhibülmahzen diğerleriyle kıyaslandığında siyasî ve idarî açıdan nispeten geri planda kalsa da, halife ve diğer üst düzey devlet adamlarıyla kurduğu ilişkiler sayesinde zaman zaman vezirliğe vekâlet etmek üzere (nâibülvezîr) görevlendirilmiştir. Hatta, İbnü'l-Attâr örneğinde görüleceği üzere, üst bürokraside elde ettikleri nüfuz sayesinde bazı devlet adamlarının gözden düşmesinde ve görevlerinden azledilmesinde etkili olabilmişlerdir.

Abbâsîler'de vezirlik müessesesinin tarihî gelişimine bakıldığında bu kurumun başında bulunan kişilerin zaman zaman başta halife olmak üzere üst düzey devlet görevlileriyle büyük bir rekabet içinde oldukları görülmektedir. Erken dönemlerde daha çok vezirliğe namzet olan şahısların birbirleriyle ve hâciblerle, kısmen de asker sınıfiyla vezirler arasında yaşanan bu rekabet, VI. (XII.) asrın başlarından itibaren üstâdâr ve sâhibülmahzen gibi farklı makamlardaki kişilerin de dahil olmasıyla daha geniş bir çevrede yaşanmaya başlamıştır. Sonu azil, hapis, müsadere ve öldürülmeyle biten bu düşmanlıkların altında yatan temel nedenin halife, vezir,

4 Üstâdâr kelimesinin kökeni ve bir kurum olarak Abbâsîler'de ortaya çıkışıyla ilgili geniş bilgi için bk. Saim Yılmaz, "Abbâsîler'de Üstâdârlık Müessesesinin Ortaya Çıkışı", İslâm Araşttrmalan Dergisi, 21 (2009), s. 1-24; Fatih Yahya Ayaz, "Üstâdüddâr", İslam Ansiklopedisi, C 42, Türkiye Diyanet Vakfi, İstanbul 2012, s. 393-395. 
ordu komutanı, hâcib, üstâdâr ve sâhibülmahzen gibi idarenin başlıca unsuru sayılan bu şahısların birbirlerinin hâkimiyet alanına müdahele ederek siyasî ve idarî açıdan kendi nüfuzlarını arttırmak istemeleri olduğu anlaşılmaktadır. Resmî kurumların yapısında ve işleyişinde ciddi zaafiyetlere neden olan bu çekişmeler devletin yıkılışına kadar devam etmiştir.

Abbâsîler'in erken dönemlerinden itibaren başta vezirlik olmak üzere yüksek dereceli memurluklar belli ailelerin güç mücadelesine sahne olmuş ve bu mücadele birkaç nesil boyunca devam etmiştir. Bu ailelerden birisi de V. ve VI. (XI. ve XII.) asırlarda vezirlik ve üstâdârlık gibi kurumların yönetiminde etkin bir rol oynayan İbnü'l-Müslime ailesidir. Nitekim yukarıda da zikredildiği üzere Resîsürrüesâ İbnü'l-Müslime önce Kâîm-Biemrillâh'ın özel kâtipliğini, ardından vezirliğini yapmış, oğlu Ebü'l-Feth Muzaffer de yine Kâim-Biemrillâh döneminde nâibülvezîrlik görevini üstlenmiştir. Ebü'l-Feth Muzaffer'in torunu İzzüddîn Abdullah b. Hibetullah, Muktefî-Liemrillâh (530-555/1136-1160) tarafindan üstâdârlığa getirilmiştir. İzzüddîn Abdullah'ın vefatından sonra oğlu Aduddüddîn İbnü'l-Müslime onun yerine üstâdârlığa tayin edilmiş ve bu görevini yeni halife Müstencid-Billâh (555-566/1160-1170) zamanında da devam ettirmiştir. MüstazîBiemrillâh (566-575/1170-1180) döneminde ise vezir olarak görevlendirilen Aduddüddîn İbnü'l-Müslime birkaç yıllık azil sürecinden sonra tekrar eski vazifesine dönmüş ve ölümüne kadar vezirlik makamında kalmıştır.

Daha önce tarafımızdan hazırlanan bir çalışmada İbnü’l-Müslime ailesinin Abbâsî idarî tarihindeki ilk temsilcisi kabul edilen Reîsürrüesâ İbnü'l-Müslime’nin meslekî kariyeri ve siyasî faaliyetleri incelenmişti ${ }^{5}$. Bu makalede ise ailenin son güçlü temsilcisi olan Adudüddîn İbnü'l-Müslime'nin bir üstâdâr ve vezir olarak halife ve diğer siyasî güç sahipleriyle girdiği iktidar mücadelesi ele alınmıştır. Bunun için öncelikle Adudüddîn’in ailesi, yetişmesi ve üstâdârlık yaptığı dönemde Vezir İbn Hübeyre'nin zehirlenmesinde herhangi bir dahlinin olup olmadığı meselesi üzerinde durulmuş, ayrıca Halife Müstencid ve sabık vezir Ebû Ca ‘fer Ahmed b. el-Beledî (İbnü'l-Beledî) ile ilişkileri incelenmiştir. Ardından Halife Müstencid'in öldürülmesindeki rolü, Müstazî tarafindan vezirliğge tayin edilmesi ve Emîr Kutbüddîn Kaymâz'la mücadelesi hakkında bilgi verilmiştir. Son olarak Müstazî ile arasının açılması ve öldürülmesi ele alınmıştır. Bütün bunların yanında konu bütünlügünü sağlamak amacıyla Adudüddîn İbnü'l-Müslime’nin çevresindeki şahısların birbirleriyle ilişkilerine de işaret edilmiştir. Makalenin son kısmına ise İbnü'l-Müslime ailesine ait bir soyağacı konulmuştur.

5 Hançabay, Abbâsîler Döneminde Vezirlik, s. 268-283.

Belleten, Ağustos 2021, Cilt: 85/Say1: 303; 423-461 
Tespit edebildiğimiz kadarıyla Türkçe literatürde Adudüddîn İbnü’l-Müslime ile ilgili müstakil bir çalışma bulunmamaktadır. Yabancı dillerdeki çalışmalara bakıldığında ise İbnü'l-Müslime'nin hayatını merkeze alarak VI. (XII.) asırda Bağdat'ta siyasî ve idarî açıdan güç ve himâye (patronage) meselesi üzerinde duran P. A. Mackay'in makalesi dikkat çekmektedir 6 . Vezir Ebü'l-Muzaffer Avnüddîn İbn Hübeyre'nin Hanbelî mezhebini siyasî ve idarî bakımdan bir baskı unsuru olarak kullandığını öne süren Mackay, Aduddüddîn İbnü'l-Müslime'nin bu baskıdan rahatsız olan Bağdat'ın önde gelen ailelerinin doğal lideri haline geldiğini iddia etmektedir. Söz konusu makale bazı açlardan bizim için yol gösterici olmakla birlikte, Mackay'in özellikle mezheplerin idarî ve ekonomik hadiseler üzerindeki etkisi ve yine bununla irtibatlı olarak Adudüddîn İbnü'l-Müslime'nin sabık vezir İbn Hübeyre ile ilişkisine dair ortaya koyduğu görüşlere katılmadığımızı belirtmeliyiz.

Subhî Mahmûd el-Azzâm'in Büveyhî nüfuzunun sona ermesinden Abbâsîler'in yıkılışına kadar geçen süre zarfinda vezirlik kurumunun tarihî gelişimini incelediği doktora tezinde Aduddüddîn İbnü'l-Müslime hakkında bazı bilgilere ulaşmak mümkündür7 . Ancak Azzâm, Mackay'in öne sürdüğü görüşlere hiç değinmediği gibi İbn Hübeyre'nin öldürülmesiyle ilgili meselede İbnü'l-Müslime'nin rolüne dair nispeten muhtasar bilgiler vermiştir. Bu açıdan söz konusu çalışma bazı rivayetlerin tespit edilmesinde bizim için faydalı olmakla birlikte elde edilen bilgilerin değerlendirilmesinde Azzâm'dan daha farklı sonuçlara ulaştığımızı özellikle belirtmemiz gerekir.

\section{Adudüddîn İbnü'l-Müslime'nin Ailesi ve Yetişmesi}

Hatîb el-Bağdâdî’nin (ö. 463/1071) Târîh'ine yazdığı zeyille tanınan İbnü'dDübeysînnin (ö. 637/1239) verdiği bilgiye göre İbnü’l-Müslime ismi Müslime lakabıyla tanınan Hamîde bint Amr isimli bir kadına dayanmaktadır. 263 (876877) yılında müslüman olan ve muhtemelen bundan dolayı Müslime ismini alan Hamîde bint Amr, Yezîd b. Mansûr isimli bir kâtiple evlenmiş ve bu evlilikten Ebû Ca‘fer Muhammed b. Yezîd dünyaya gelmiştir. Ebû Ca'fer Muhammed’in Ümmü Külsûm isimli kadınla yaptığı evlilikten Kurretü’l-Ayn adıyla tanınan, ancak daha çok İbnetü'l-Müslime lakabıyla bilinen bir kızları olmuştur. İbnetü'l-Müslime

6 P. A. Mackay, "Patronage and Power in 6th/12th Century Baghdad. The Life of the Vizier 'Adud al-Dīn Ibn Al-Muzaffar", Studia Islamica, 34 (1971), s. 27-56.

7 Subhî Mahmûd el-Azzâm, el-Vizâretii'l-Abbâsiyye (h. 447-656/m. 1055-1258) (doktora tezi), elCâmi'atü'l-Ürdüniyye, Külliyyetü'd-Dirâsâti'l-'Ulyâ, Amman 2000, s. 140-141, 149-150, 177 $185,196$. 
ile Ebü'l-Ferec Hasan b. Ubeyd b. Amr b. Hâlid b. er-Rüfeyl'in evliliklerinden sonra bu ikisinin soyundan gelen kişiler Benû Müslime veya İbnü'l-Müslime lakabıyla tanınmışlardır ${ }^{8}$. İbnü’l-Müslime lakabıyla anılan ilk kişinin Ebü’l-Ferec Hasan'ın torunun oğlu Ebü'l-Ferec İbnü'l-Müslime Ahmed b. Muhammed b. Ömer (ö. 415/1024) olduğu söylenmektedir ${ }^{9}$. Ahmed b. Muhammed b. Ömer ise Reîsürrüesâ İbnü’l-Müslime'nin dedesidir ${ }^{10}$.

Adudüddîn İbnü'l-Müslime'nin dedesinin dedesi Reîsürrüesâ İbnü'l-Müslime Abbâsî halifeliği üzerinde Irak Büveyhîleri'nin (334-447/945-1055) nüfuzunun sona erip Büyük Selçuklular'ın (431-552/1040-1157) nüfuzunun başladığı bir dönemde Kâim-Biemrillâh'ın önce katipliğini, 437 (1045) yllından itibaren de vezirliğini yapmıştır. İbnü'l-Müslime ailesinin Abbâsî idarî tarihindeki muhtemelen ilk temsilcisi olan ve kâtiplik mesleğindeki maharetinin yanında "itikadı sağlam" ve "akıl sahibi" gibi müspet ifadelerle anılan Reîsürrüesâ İbnü'l-Müslime’nin vezirliğe tayin edilmesiyle Abbâsîler'de yaklaşık bir asırdır atıl bir vaziyette bulunan vezirlik kurumu yeniden işlerlik kazanmaya başlamıştır. On üç yll vezirlik yapan Resîsürrüesâ İbnü'l-Müslime bu süreçte bir taraftan Irak Büveyhîleri'nin Bağdat'taki varlıklarının ortadan kalkması için büyük bir mücadele vermiş, diğer taraftan Selçuklu sultanları ve devlet adamlarına karşı denge siyaseti izleyerek Abbâsî halifeliğinin güçlenmesi için gayret sarfetmiştiir ${ }^{11}$.

Reisürrüesâ İbnü'l-Müslime'den sonra onun neslinden gelen kişiler Abbâsî idaresinde çeşitli görevler üstlenmeye devam etmişlerdir. Nitekim Reîsürrüesâ İbnü'l-Müslime'nin oğlu Ebü'l-Feth Muzaffer, Muktedî-Biemrillâh (467487/1075-1094) döneminde Amîdüddevle Muhammed b. Fahrüddevle b. Cehîr'in (ö. 493/1100) birinci vezirliğinden ${ }^{12}$ ayrilmasılyla (25 Safer 476/14

8 Ebû Abdullah Cemâlüddîn Muhammed b. Saîd İbnü’d-Dübeysî, Zeylï Târîhi Medîneti’s-selâm (nşr. Beşşâr Avvâd Ma'rûf), I-V, Dârü'l-Garbi'l-İslâmî, Beyrut 1427/2006, C I, s. 371.

9 Claude Cahen, "Ibn al-Muslima", The Encyclopaedia of Islam New Edition, C 3, Brill, Leiden 1986, s. 891.

10 Ebü'l-Ferec Cemâlüddîn Abdurrahman b. Alî b. Muhammed el-Bağdâdî İbnü'l-Cevzî, el-Muntazam fì târîhi'l-mülûk ve'l-ümem (nşr. Muhammed Abdülkadir Atâ \& Mustafa Abdülkadir Atâ), I-XIX, Dârü'l-Kütübi'l-İlmiyye, Beyrut 1412/1992, C XV, s. 164-165.

11 Reîsürrüesâ İbnü'l-Müslime’nin vezirliği ve bu süreçteki faaliyetleriyle ilgili geniş bilgi için bk. Hançabay, Abbâsiler Döneminde Vezirlik, s. 268-283.

12 Amîdüddevle Muhammed b. Cehîr, Muktedî-Biemrillâh ve Müstazhir-Billâh (487-512/10941118) dönemlerinde iki defa vezirliğe tayin edilmiştir. İkinci vezirliği 19 Safer 484 (12 Nisan 1091) tarihinde sona ermiştir. Amîdüddevle'nin babası Fahrüddevle de Kâim-Biemrillâh döneminde vezirlik yapmıştır. Benû Cehîr ailesinin Abbâsî idarî tarihindeki etkinliği ile ilgili geniş bilgi için bk. Hançabay, Abbâsiler Döneminde Vezirlik, s. 290-310, 313-317; Eric Hanne, "The Banū Jahīr and 
Temmuz 1083) bir müddet vezirin uhdesindeki işlerle ilgilenmek üzere vekâleten görevlendirilmiştir ${ }^{13}$. Kaynaklarda sadece edipliğine ve faziletli bir kişi olmasına işaret edilen Ebü'l-Feth Muzaffer'in oğlu Ubeydullah'ın ${ }^{14}$ (ö. 526/1131-1132) ise devlet kademesinde görev alıp almadığına dair herhangi bir bilgi bulunmamaktadır. Ubeydullah b. Muzaffer’in oğlu ve aynı zamanda Adüdüddîn İbnü'l-Müslime’nin babası İzzüddîn Abdullah b. Hibetullah 535 (1140-1141) yllında MuktefîLiemrillâh’ın üstâdârlığına tayin edilmiş ve vefatına kadar bu görevini devam ettirmiştir (549/1154-1155) $)^{15}$.

Adudüddîn'in oğullarından Kemâlüddîn Ebü'l-Fazl Ubeydullah (ö. 576/11801181) babasının vezir olarak görevlendirilmesiyle onun yerine üstâdârlı̆̆a tayin edilmiştir. Üstâdârlık görevinin dışında edipliğiyle de tanınan Kemâlüddîn’in ahlâkî açıdan zayıf bir kişiliğe sahip olduğu söylenmektedir ${ }^{16}$. Adudüddîn’in bir diğer oğlu Ebû Nasr Alî ise babasının öldürülmesinin ardından tasavvufî bir hayat tarzını benimsemiş ve bir müddet Dârülhilâfe'de ${ }^{17}$ inşâ ettirdiği ribâtta ${ }^{18}$

Their Role in the Abbāsid and Saljuq Administrations", Al-Masaq: Islam and Medieval Mediterranean, 20 (2008), s. 29-45; Abdülkerim Özaydın, "Benî Cehîr", İslâm Ansiklopedisi, C 5, Türkiye Diyanet Vakfi, İstanbul 1992, s. 447-449.

13 İbnü'l-Cevzî, el-Muntazam, C XVI, s. 200.

14 İbnü'l-Cevzî, el-Muntazam, C XVII, s. 273.

15 Selâhuddîn Halîl b. Aybeg es-Safedî, el-Vâfi bi'l-vefeyât (nşr. Ahmed el-Arnaûd \& Türkî Mustafa), I-XIX, Dâru İhyâi't-Türâsi'l-Arabî, Beyrut 1420/2000, C XVII, s. 354.

16 Safedî, el-Vâfĭ, C XIX, s. 267.

17 Abbâsîler döneminde halife sarayını ve müştemilâtını ifade etmek için kullanılan Dârülhilâfe, devletin erken döneminde Ebû Ca'fer el-Mansûr'un (136-158/754-775) Dicle nehrinin batısında yaptırdığı, etrafı surlarla çevrili dairevî şehrin içinde bulunuyordu. Mehdî-Billâh (158-169/775785 ) halife olunca Dârülhilâfe'yi nehrin doğusunda bulunan Rusâfe'ye taşıdı. Hadî-İlelhâk (169170/785-786) da burada ikâmet etti. Ancak Hârûnurreșid'le (170-193/786-809) birlikte tekrar Dicle'nin batı yakasına nakledilen Dârülhilâfe, Sâmerrâ'dan sonra Bağdat'in yeniden devlet merkezi haline gelmesiyle (279/892) nehrin doğu tarafina taşındı. Bu süreçte halife sarayı ve sarayın etrafında bulunan yerleşim yerlerini içine alacak şekilde anlamı ve sınırları genişleyen Dârülhilâfe, Rusâfe'nin güneyindeki Sûkusselâse'nin aşağı kısmında teşekkül etmeye başladı ve devletin yıkılışına kadar burada kaldı. Geniş bilgi için bk. Abdulhamit Dündar, 4/10. Yüzynlda Bağgat (Topografya, Toplumsal Yapr, Gündelik Hayat) (doktora tezi), Şeyh Edebali Üniversitesi, Sosyal Bilimler Enstitüsü, Bilecik 2019, s. 57, 85, 134-136; Saim Yılmaz-Ömer Sazak, "Doğu Bağdat'ta Dârülhilâfe'nin Ortaya Çıkışı ve Burada İnşa Edilen Saraylar (279-334/892-945)", Sakarya Üniversitesi İlahiyat Fakültesi Dergisi, 42 (2020), s. 285-313; Ramazan Şeşen, "Dârülhilâfe", İslam Ansiklopedisi, C 8, Türkiye Diyanet Vakfi, İstanbul 1993, s. 538-539.

18 Sınır boylarında ve stratejik mevkilerde askerî amaçlı müstahkem yapılara verilen addır. Ancak bu yapılar sınırların genişlemesiyle askerî karakterlerini kaybedip dinî ve tasavvufî bir karaktere bürünmüşlerdir. Söz konusu yapılarda zikir ve riyâzet askerî eğitim ve hazırlıkların yerini almıştır. Dahası tasavvufun gelişmesi ribâtlara yeni bir işlev kazandırmış ve ribâtlar giderek birer tekke ve 
kalmıştır. Daha sonra Selâhaddîn-i Eyyûbî’nin (567-589/1171-1193) yanına giden Ebû Nasr, Vezir İbn Hübeyre'nin (ö. 560/1165) soyundan gelen bazı kişilerin düşmanlıklarına rağmen Selâhaddîn-i Eyyûbî tarafindan büyük bir teveccühle karşılanmış ve vefatına kadar Dımaşk'ta yaşamıştır (Cemâziyelâhir 582/EylülAğustos 1186 [?] $)^{19}$. Kaynaklarda Adudüddîn'in Ebû Mansûr el-Ferec ve Ebü'lHasan Abdullah isminde iki oğlundan daha bahsedilmektedir. Ancak isimlerinin dışında bu kişiler hakkında her hangi bir bilgi bulunmamaktadır ${ }^{20}$.

Cemâziyelâhir 514 (1120) tarihinde dünyaya gelen Adudüddîn İbnü’l-Müslime'nin tam adı Ebü'l-Ferec Adudüddîn Muhammed b. Abdullah b. Hibetullah b. elMuzaffer b. el-Müslime'dir ${ }^{21}$. Ancak daha çok İbnü'l-Müslime ve Adudüddîn lakaplarıyla tanınmaktadır. İbnü'l-Müslime lakabı mensup olduğu aileye nispetle verilmiştir. Adudüddîn lakabını ise vezirliğe atandığında almıştır. Küçük yaşlarda Kur'ân'ı ezberleyip fikıh ve edebiyatla ilgilenen İbnü'l-Müslime aynı zamanda hadis rivayetiyle de meşgul olmuştur ${ }^{22}$. Nitekim Ebü'l-Hasan Ubeydullah b. Muhammed el-Beyhakî (ö. 523/1129), Ebü'l-Kâsım Hibetullah b. Muhammed b. Husayn (ö. 525/1131), Ebû Mansûr Muhammed b. Abdülmelik b. Hayrûn (ö. 539/1144) ve Ebü'l-Kâsım Zâhir b. Tâhir en-Nîsâbûrî (ö. 533/1138) gibi muhaddislerden hadis rivayet etmiştir. Kendisinden de Ebü'l-Mahâsin Kâdı Ömer b. Alî el-Kureşî (ö. 575/1179-1180), Ebû Bekr Muhammed b. Ebî Gâlib alBâkıdârî (ö. 604/1207), Ebû Ahmed Dâvud b. Alî (ö. ?), Ebû Ahmed b. Ebî Nasr bin el-Muzaffer (ö. ?) gibi kişiler rivayette bulunmuşlardır ${ }^{23}$.

zâviyeye dönüşmüştür. Geniş bilgi için bk. İsmail Yiğit, "Ribât", İslâm Ansiklopedisi, C 35, Türkiye Diyanet Vakfi, İstanbul 2008, s. 76-79.

19 Ebü'l-Muzaffer Şemsüddîn Yûsuf b. Kızoğlu Sıbt İbnü'l-Cevzî, Mir'âtü'z-zamân fî tevârîhi'l-a'yân (nşr. Muhammed Berakât-vd), I-XXIII, er-Risâletü'l-Âlemiyye, Dımaşk 1434/2013, C XXI, s. 315-316.

20 Ebü'l-Feth Muhammed b. Ubeydillâh Sıbt İbnü’t-Teâvîzî, Dîvân (nşr. David Samuel Margoliouth), Matba'atu'l-Muktataf, Kahire 1903, s. 464. Ayrica bk. Mackay, "Patronage and Power", s. 53.

21 İbnü'l-Cevzî, el-Muntazam, C XVIII, s. 246; Sıbt İbnü'l-Cevzî, Mir'âtï'z-zamân, C XXI, s. 253; Ebû Abdullah Şemsüddîn Muhammed b. Ahmed b. Osmân ez-Zehebî, Siyeru a 'lâmi'n-nübelâ' (nşr. Şuayb el-Arnaût-vd.), I-XXV,: Müessesetü'r-Risâle, Beyrut 1403/1983, C XXI, s. 75.

22 İbnü'l-Cevzî, el-Muntazam, C XVIII, s. 246; Zehebî, Siyeru a'lâmi’n-nübelâ', C XXI, s. 75. Ayrıca bk. Sıbt İbnü'l-Gevzî, Mir'âtiu'z-zamân, C XXI, s. 253.

23 Ebû Abdullah Şemsüddîn Muhammed b. Ahmed b. Osmân ez-Zehebî, el-Muhtasarü'l-muhtâc ileyhi min Târîhi İbni'd-Dübeysî (nşr. Mustafa Cevâd), I-III, Matba'atü'z-Zamân, Bağdat 1951-1977, C I, s. $56-57$. 


\section{2. Üstâdârlığı}

\section{a. Vezir İbn Hübeyre'nin Öldürülmesindeki Rolü}

İbnü'l-Müslime ilk defa Muktefî zamanında babası İzzüddîn Abdullah b. Hibetullah'n vefatıyla birlikte onun yerine üstâdârlı̆ga tayin edilmiş ve bu görevini Müstencid-Billâh döneminde de devam ettirmiştir ${ }^{24}$. Üstâdârlık görevini devraldıktan sonra bilhassa divanların işleyişinde önemli bir nüfuz elde eden İbnü'l-Müslime, Vezir İbn Hübeyre’nin 13 Cemâziyelevvel 560 (28 Mart 1165) tarihindeki ani vefatıyla birlikte söz konusu makama atanması muhtemel en güçlü aday olarak öne çıkmıştır25. Ancak İbnü'l-Müslime sahip olduğu bu nüfuza rağmen altı yıl boyunca vezirliğe atanamamıştır. Diğger taraftan üstâdârlık yaptığı dönemde kendisiyle ilgili dile getirilen en önemli husus Vezir İbn Hübeyre'nin şüpheli ölümüyle sonuçlanan olayların arkasındaki şahıslardan birisi olup olmadığıdır. Kaynaklar İbn Hübeyre'nin zehirlenerek vefat ettiği hususunda büyük oranda ittifak halinde olmalarına rağmen bu işin arkasında gerçekten kimin olduğuna dair herhangi bir bilgi vermemişlerdir ${ }^{26}$. Dolayısıyla mevcut bilgiler doğrultusunda İbn Hübeyre'yi kimin öldürttügüne dair kesin bir şey söylemek mümkün görünmemektedir.

Bununla birlikte bazı araştırmacılar söz konusu hadisede İbn Müslime'nin bir dahlinin olabileceğini ileri sürmektedir. İbn Hübeyre'nin vefatından kısa bir süre önce Üstâdâr İbnü'l-Müslime'nin onun yanında bulunmasının olaya farklı bir boyut Eserî \& Cemîl Saîd), I-V, Matba‘atü Mecma‘i’l-İlmî el-Irâkî, Bağdat 1955-1964, C V, s. 506-507; İbnü'l-Cevzî, el-Muntazam, G XVIII, s. 164, 168-169; Halil İbrahim Hançabay, "Abbâsîler'in Son Dönem Vezirlerinden Ebü'l-Muzaffer Yahya b. Hübeyre (ö. 560/1165)", Marmara Üniversitesi Illahiyat Fakültesi Dergisi, 53 (2017), s. 67-70. Ayrıca bk. Ebü'l-Abbâs Şemsüddîn Ahmed b. Muhammed İbn Hallikân, Vefeyâtü'l-'ayân ve enbâü ebnâi'z-zamân (nşr. İhsan Abbâs), I-VIII, Dâru Sâdır, Beyrut 1398/1978, C VI, s. 236, 240; Ebû Abdullah Şemsüddîn Muhammed b. Ahmed b. Osmân ez-Zehebî, Târîhu'l-İslâm ve vefeyâtü'l-meșâhir ve'l'alâm: sene 551-560 (nşr. Ömer Abdüsselâm Tedmürî), Dârü'l-Kütübi'l-Arabî, Beyrut 1411-1421/1991-2000, s. 332-333; Zeynüddîn Ebü'lFerec Abdurrahman b. Şihâbüddîn Ahmed İbn Receb, ez-Zeyl 'alâ Tabakâti'l-Hanâbile, I-II, Dârü'lMa'rife, Beyrut [ts.], C I, s. 285-286; Sibt İbnü'l-Gevzî, Mir'âtü'z-zamân, C XXI, s. 63. 
kazandırdığını ifade eden Mason, İbn Hübeyre'den sonra vezirliğe tayin edilenlerin hızla değiştiğini ve İbnü'l-Müslime’nin isminin öne plana çıktığını söylemektedir ${ }^{27}$. Anlaşıldığı kadarıyla Mason, söz konusu süreçte İbnü'l-Müslime'nin nüfuzunu korumasından hareketle İbn Hübeyre'nin zehirlenmesinde onun bir rol oynamış olabileceğini düşünmektedir. Yine günümüz araştırmacılarından Azzâm, İbnü'lMüslime ve Hâcib Muhammed b. Abdullah ile İbn Hübeyre arasında gizli bir düşmanlığın bulunduğunu söyleyerek, söz konusu meselenin arkasında İbnü’lMüslime'nin olabileceğine dair bir ihtimale işaret etmektedir ${ }^{28}$.

Mason ve Azzâm dışında, İbn Hübeyre ile İbnü'l-Müslime arasındaki ilişkiyi mezheplerin ve iktisadî faktörlerin etkisi açısından daha farklı boyutlarda yorumlayan araştırmacılar da vardır. Nitekim VI. (XII.) asırda mezheplerin idarî ve siyasî olaylar üzerindeki etkisine özel bir önem atfeden Mackay, bu dönemde Bağdat'taki siyasî hadiselerin en önemli taraflarından birisini dünyevî (secular) ilgilerle [ekonomik faaliyetler ve devletin idarî kadrolarına yapılan atamalar] mezhepler arasındaki ilişkilerin oluşturduğunu ve İbnü'l-Müslime ile ittifak halinde olan Bağdat'ın sermaye sahibi ileri gelen ailelerinin Şafî̀ veya Hanefî mezhebine mensup olduğunu öne sürmektedir ${ }^{29}$. Mackay ayrıca Abbâsîler'in Irak Selçukluları'na (511-590/1118-1194) yönelik gerçekleştirdiği askerî faaliyetlerden dolayı devletin önemli bir gelire ihtiyaç duyduğunu, bir vezir olarak İbn Hübeyre'nin ise bu ihtiyacı vergiler üzerinde bazı düzenlemeler yaparak karşılamaya çalıştığını ve [bu uygulamaya karşı çıkması muhtemel] bazı kadıların görevlerine son verdiğini belirtmektedir ${ }^{30}$. Görüşlerinin devamında Mackay, vezirliğinin yanında Hanbelî bir fakih olmasıyla da tanınan İbn Hübeyre'nin doğrudan mükûs, yani gayr-i şer î vergilere başvuramayacağını, bunun yerine geleneksel vergilerin toplanma sisteminde bir değişikliğe gideceğini, bu durumda ise öncelikle kâdılkudâttan gelebilecek tepkiyi bertaraf etmesi gerektiğini söylemektedir. Bu noktada İbn Hübeyre'nin açıkça Kâdılkudât Ebü’l-Hasan Alî b. Ahmed ed-Dâmegânî’ye (ö. 583/1188) tepki göstermesinin doğru olmayacağını belirten Mackay, bunun yerine onun önce [daha düşük rütbeli bir kadılık makamına sahip olan] Kadı İbnü'lMurahhim'ỉi görevinden azlettiğini, ardından iktâ arazilerini harâcî araziye

27 Herbert Mason, Two Statesmen of Medieval Islam: Vizir Ibn Hubayra and Caliph an-Nâsir li Dîn Allâh, Mouton Publishers, Netherlands 1972, s. 54-55.

28 Azzâm, el-Vizâretü'l-Abbâsiyye, s. 177.

29 Mackay, "Patronage and Power", s. 29.

30 Mackay, "Patronage and Power", s. 32-33.

31 İbnü'l-Murahhim'in ismini Ibn al-Markham şeklinde telaffuz eden Mason (Two Statesmen of 
dönüştürdüğünü aktarmaktadır. Buna göre arazilerin statüsündeki bu değişiklik devlete büyük bir gelir getirmesine rağmen toplumun hemen bütün kesimleri bu uygulamadan olumsuz etkilenmiştir ${ }^{32}$. Vergilerle ilgili yapılan düzenlemelerin insanları zor duruma düşüren tek sorun olmadığını söyleyen Mackay'e göre Hanbelîlik dışındaki diğer mezheplerin mensupları, özellikle de dönemin Hanbelî olmayan önde gelen aileleri, İbn Hübeyre'nin Hanbelîlik düşüncesinin gittikçe etkisini arttırmasından dolayı endişelenmeye başlamışlardır. Bu noktada fakir bir aileye mensup olan İbn Hübeyre ile kıyaslandığında köklü bir aile geleneğine sahip olan İbnü'l-Müslime'nin ismi öne çımış ve İbnü'l-Müslime söz konusu ailelerin doğal lideri haline gelmiştir ${ }^{33}$. Büyük oranda Mackay'in görüşlerine dayanan Kucur ise ortaya çıkan bu huzursuzluk ortamında İbn Hübeyre'nin gücünü zayıflatarak dengeyi sağlamayı amaçlayan Halife Müstencid’in Üstâdâr İbnü'l-Müslime'yi desteklediğini ileri sürmektedir ${ }^{34}$.

Mackay'in anlatımlarında Hanefî mezhebine mensup Kâdılkudât İbnü’dDâmegânî̀yi doğrudan karşısına almak istemeyen İbn Hübeyre, bunun yerine kendi planını uygulamak için önce Kadı İbnü'l-Murahhim’i görevinden azletmiştir. Ancak Mackay ısrarla mezheplerin siyasî ve idarî olaylar üzerindeki etkisinden bahsetmesine rağmen İbnü'l-Murahhim'le İbnü'd-Dâmegânî arasında ne tür bir ilişki olduğuna dair bir izahta bulunmadığı gibi İbnü'l-Murahhim'in mezhebiyle ilgili herhangi bir açıklama da yapmamıştır. Ayrıca kaynaklarda İbnü’lMurahhim'in görevinden alınmasiyla ilgili aktarlan rivayetlere bakılacak olursa, Mackay’in da zikrettiği üzere, bu kararın arkasındaki en önemli nedenlerden birisi İbnü'l-Murahhim'in görevini kötüye kullanması ve insanlardan rüşvet almasıdır. Görevinden azledildikten sonra malları müsadere edilen İbnü'l-Murahhim’in

Medieval Islam, 54, dn. 53) İbnü'l-Esîr'in eserinde geçen bilgilere dayanarak onun kâdılkudât olduğunu iddia etmektedir. Bk. Ebü'l-Hasen İzzüddîn Alî b. Muhammed İbnü'l-Esîr, el-Kâmil fi't-târîh (nşr. Carl Joan Tornberg), I-XII, Dâru Sâdır \& Dâru Beyrut, Beyrut 1965, C IX, s. 97. Ancak el-Kâmil'de İbnü'l-Murahhim'in kâdılkudât değil, sadece kadı olduğu söylenmektedir. (el-Kâmil, C XI, s. 258). Kâdılkudâtlık kurumuyla ilgili yapılan modern çalışmalarda da İbnü'lMurahhim'in ismi kâdılkudâtların arasında zikredilmemiştir. Abbbâsîler döneminde görev yapmış kâdılkudâtların bir listesi için bk. Safiyye Saâ'de, Tatavouru mansıbi'l-kâd'l'-kudât fi'l-fetreteyn el-Büveyhiyye ve's-Selcûkiyye, Dâru Emvâc, Beyrut 1988, s. 185-188; Yavuz Selim Göl, Abbâsîler Döneminde Kâdi'l-kudâthk (doktora tezi), Necmettin Erbakan Üniversitesi, Sosyal Bilimler Enstitüsü, Konya 2018, s. 115-177.

32 Mackay, "Patronage and Power", s. 33-35.

33 Mackay, "Patronage and Power", s. 35.

34 Sadi S. Kucur, "İbnü’l-Müslime, Adudüddin”, İslâm Ansiklopedisi, C 21, Türkiye Diyanet Vakfi, İstanbul 2000, s. 160. 
içlerinde İbn Sinâ'nn eş-Şifâ isimli eseriyle İhvân-1 Safầnın risâlelerinin bulunduğu kitapları yakılmıştır. Ardından hapse atılan İbnü'l-Murahhim kısa bir süre sonra ölmüştür ${ }^{35}$.

Meslekî açıdan yetersiz olması ve uygunsuz davranışlar sergilemesi sebebiyle görevinden azledilen İbnü'l-Murahhim'in tutuklandıktan sonra elinde bulunan felsefî içerikli kitapların yakılması, diğer mezheplerle kıyaslandığında bu konuda nispeten katı bir tavır sergileyen Hanbelîlik'in daha baskın olduğunu gösterebilir. Nitekim aynı süreçte Halife Müstencid'e yakınlı̆̆ı sebebiyle İbn Hübeyre tarafindan kıskanıldığı söylenen Tevbe b. el-Ukaylî isimli şahsın yanında acemlere [İbnü'l-Muharrim'le ilgili rivayette geçtiği üzere İbn Sînâ ve benzerlerinin kitapları olmalı] ait bazı kitapların bulunduğu gerekçesiyle tutuklanmasi ${ }^{36}$ bu dönemde Hanbelîlik'in etkin olduğunu ve belki felsefî ilimlere ilgi duyan veya Hanbelî mezhebine mensup olmayan kimselerin kısmen tedirginlik yaşadıklarını gösteren bir başka örnek olarak zikredilebilir. Bununla birlikte kaynaklarda söz konusu durumun, Üstâdâr İbnü'l-Müslime'yi mevcut şartlardan rahatsız olan zümrenin lideri haline getirdiği veya halifenin İbn Hübeyre'ye karşı dengeyi sağlamak için İbnü’l-Müslime'yi desteklediğine dair bir veri bulunmamaktadır. Bu noktada Mackay, makalesinin ilerleyen sayfalarında kendi görüşünü desteklemek için İbnü'l-Müslime'nin vezirliğe tayin edilmesiyle Hanbelî mezhebine mensup olmayan kişilerin yeniden devlet kademesinde görev almaya başladıklarını, örnek olarak da Ebü'l-Mahâsin Ömer b. Alî el-Kureşî’nin (ö. 575/1179-1180) Nehrü'l-muallâ ${ }^{37}$ kadılığına tayin edildiğini ifade etmektedir ${ }^{38}$. Ancak Mackay'in tek bir örnek üzerinden genel bir yargıya vardığı anlaşılmaktadır. Diğer taraftan vezirliğinin yanı sıra döneminin önde gelen Hanbelî fakihlerinden birisi olmasıyla tanınan İbn Hübeyre'nin kendi mezhebi içerisinde mutedil bir görüşe sahip olduğu ve çeşitli mezheplere mensup âlimlerin onu sevip ilmî konularda kendisiyle istişare

35 İbnü'l-Cevzî, el-Muntazam, C XVIII, s. 140-141; İbnü'l-Esîr, el-Kâmil, C XI, s. 258, 362.

36 İbnü'l-Esîr, el-Kâmil, C XI, s. 320. Tevbe b. el-Ukaylî’nin ismini Tevbe el-Bedevî olarak zikreden İbnü'l-Cevzî onun Hemedân halkının Bağdat'a yönelik yapmayı planladıkları isyana katılmayı düşündüğü için öldürüldüğünü söylemektedir. Bk. İbnü’l-Cevzî, el-Muntazam, C XVIII, s. 162163.

37 Bağdat'ın doğu yakasında yer alan en büyük ve en meşhur mahallelerden birisidir. Geniş bilgi için bk. Yâkût b. Abdullah el-Hamevî, Mu'cemü'l-büldân, I-V, Dâru Sâdır, Beyrut 1397/1977, C V, s. 324.

38 Mackay, "Patronage and Power", s. 39. Kureşî’nin görevlendirilmesiyle ilgili bk. İbnü'l-Cevzî, el-Muntazam, C XVIII, s. 191. 
ettikleri bilinmektedir ${ }^{39}$. Dolayısıyla İbn Hübeyre'nin Hanbelîlik’i baskı unsuru olarak kullandığı iddiası biraz aşırı bir yorum olarak görülebilir.

Ayrıca İbnü’l-Müslime'nin köklü bir aileden geldiğini ifade eden Mackay’in, Kâim-Biemrillâh dönemi vezirlerinden ve İbnü'l-Müslime'nin de dedesinin dedesi olan Reîsürrüesâ İbnü'l-Müslime'nin Hanbelîler'e karşı bir meylinin olduğuna dair kaynaklarda geçen bilgileri40 dikkate almadığı belirtilmelidir. Nitekim bazı araştırmacılar ${ }^{41}$ bu bilgiler doğrultusunda onun "mutassıb bir Hanbelî-sünnî" oluşuna dikkat çekmektedirler. Onların bu değerlendirmelerinden hareketle İbnü’lMüslime ailesinin sonraki dönemlerde de Hanbelîler'e yönelik bir meyillerinin olmuş olabileceği öne sürülebilir. Yani bir aile geleneğinden bahsediliyorsa bu geleneğin siyasî-idarî görevler açısından olduğu kadar mezhebî aidiyet/yakınlık açısından da devam ettirilmiş olma ihtimali dikkate alınmalıdır. Bütün bunlara ek olarak İbn Hübeyre'nin icraatları arasında toplumda rahatsızlık uyandıran esas meselenin Hanbelî mezhebinin baskın bir hal almasından ziyade, iktisadî açıdan yürürlüğe konulan bazı uygulamalar olduğu özellikle ifade edilmelidir. Nitekim İbnü'l-Gevzî’nin verdiği bilgiye göre İbn Hübeyre iktâ arazilerini harâcî araziye dönüştürdüğü için insanlar onun aleyhinde konuşmaya başlamışlardı4 ${ }^{42}$.

İbn Hübeyre'nin vefatılla birlikte gelişen olayları yakından takip eden İbnü'lMüslime, son durumu öğrenmek için yakın adamlarından bazılarını vezirin evine göndermiştir ${ }^{43}$. Vefat haberinin duyulmasından sonra başta İbn Hübeyre'nin hâcibi İ̉n Türkân ve Vâsı'ta nâibliğini yapan İmâdüddîn el-İsfahânî olmak üzere vezirin yakınında bulunan bazı kişiler tutuklanmıştır. Üstâdâr İbnü'lMüslime'nin evinde gözaltında tutulan İbn Türkân gördügü işkence sonucu ölürken ${ }^{44}$, İmâdüddîn el-İsfahânî ise İ̉nü’l-Müslime’ye bir mektup göndererek

39 İbn Hübeyre'nin ilmî birikimiyle ilgili geniş bilgi için bk. İbn Hallikân, Vefeyâtü'l-'ayân, C VI, s. 230-231; Ibn Receb, ez-Zeyl, C I, s. 251-253; Mason, Two statesmen of mediaeval Islam, s. 25-37; Mehmet Aykaç, “İbn Hübeyre, Ebü’l-Muzaffer”, İslâm Ansiklopedisi, C 20, Türkiye Diyanet Vakfi, İstanbul 1999, s. 82-83.

40 İbnü'l-Esîr, el-Kâmil, C IX, s. 576.

41 Mafizullah Kabir, The Buwayhid Dynasty of Baghdad (334/946-447/1055), Iran Society, Calcutta 1964, s. 114; Süleyman Genç, Fatımî-Abbâsî Selçuklu Münasebetleri (doktora tezi), Dokuz Eylül Üniversitesi, Sosyal Bilimler Enstitüsü, İzmir 1995, s. 146, 156.

42 İbnü'l-Gevzî, el-Muntazam, C XVIII, s. 148.

43 İbn Hallikân, Vefeyât, G VI, s. 241.

44 İmâdüddîn el-İsfahânî, Harîdetiu'l-kasr, C V, s. 506-507; İbnü'l-Cevzî, el-Muntazam, C XVIII, s. 164 . 
serbest kalmayı başarmışıır ${ }^{45}$. Ayrıca İbn Hübeyre'nin iki oğlu İzzüddîn Ebû Abdullah Muhammed ve Şerefüddîn Zafer gözaltına alınarak hapse atılmıştır. Bunlardan küçük oğlu İzzüddîn hapisten kaçmayı başarmış, ancak kısa bir süre sonra yakalanarak tekrar hapse atılmış, Şerefüddîn ise hapiste iken ölmüştür (18 Safer 562/14 Aralık 1166) ${ }^{46}$. Kaynaklarda bu kişilerin gözaltına alınmasıyla ilgili herhangi bir sebep zikredilmemekle birlikte, eskiden beri devam edegelen uygulamalardan dolayı sabık vezirin yakınlarına yönelik böyle bir tavır sergilenmiş olabilir. Nitekim birçok dönemde mazul vezirin yanı sıra ona yakın kimseler takibata maruz kalmışlar veya görevlerinden azledilerek ölüme mahkûm edilmişlerdir.

İbn Hübeyre'nin vefatıyla boşalan vezirlik makamına hemen bir atama yapmayan Halife Müstencid, Kâdılkudât Ebü'l-Berekât Ca‘fer es-Sekâfî̀yi nâibülvezîr olarak görevlendirmiştir. Yaklaşı üç yll boyunca bu görevi devam ettiren Ebü’lBerekât, İbnü’l-Beledî’nin Safer 563 (Kasım-Aralık 1167) tarihinde vezirliğge tayin edilmesiyle nâibülvezîrlikten ayrılmıştır ${ }^{47}$.

\section{b. Halife Müstencid'in Öldürülmesi ve Müstazî’nin Halife Olmasındaki Rolü}

Irak Selçukluları'nın (511-590/1118-1194) Bağdat üzerindeki nüfuzunun büyük oranda sona erdiği ve Abbâsîler’in siyasî olarak yeniden güçlenmeye başladığı bir dönemde vezirlik makamının bir süre boş kalması dikkat çekmektedir. Bu süreçte İbn Hübeyre gibi hem Abbâsî halifeliğinin diğer hanedanlarla ilişkisinde hem de devletin bürokratik yapısı içinde denge oluşturabilecek güçlü bir şahsiyetin bulunmayışı sebebiyle halifenin böyle bir karar verdiği söylenebilir ${ }^{48}$. Ayrıca vezirlik için güçlü bir namzet olarak öne çıkmasına rağmen Üstâdâr İbnü'l-Müslime'nin söz konusu makama atanmaması önemli bir husus olarak görünmektedir. Bu noktada İbnü'l-Müslime'nin, etrafindaki kişilere yönelik sert tutumlarından dolayı

45 İbn Hallikân, Vefeyât, C V, s. 151.

46 İbnü'l-Gevzî, el-Muntazam, C XVIII, s. 172, 174. Ayrica bk. Sıbt İbnü'l-Gevzî, Mir'âtü'z-zamân, C XXI, s. $68,73$.

47 Safedî, el-Vâfî, C IX, s. 87; Zehebî, Târih: sene 561-570, s. 153. İbn Hallikân'ın eserinde (Vefeyât, C VI, s. 241) İbn Hübeyre'nin oğlu İzzüddîn Ebû Abdullah Muhammed'in babasının yerine vezirliğe vekâlet ettiğine dair bir bilgi yer almaktadır. Ancak İzzüddîn’in babasının vefatından hemen sonra tutuklandığı göz önünde bulundurulursa, onun bu görevi babasının hastalığı sırasında kısa bir süre yerine getirdiği anlaşılmaktadır. Bk. Mackay, "Patronage and Power", s. 36, dn. 4.

48 Benzer bir yaklaşım için bk. Ma'an Alî Ahmed el-Mukâbele, İhyâu'l-hilâfeti'l-Abbâsiyye fi'l-fetra min "530-622 h./1135-1225 m." (doktora tezi), el-Câmi'atü'l-Ürdüniyye, Külliyyetü'd-Dirâsâti'l'Ulyâ, Amman 1999, s. 121. 
kendisiyle ilgili Halife Müstencid'in zihninde bir takım soru işaretlerinin oluştuğu düşünülebilir. Nitekim Müsterşid-Billâh (512-529/1118-1135) döneminde sâhibülmahzen olarak görev yapan Hamza b. Talha'nın (İbn Talha) damadı İbnü’ş-Şemhal ve hanımı yakalanarak İbnü'l-Müslime’nin gözetiminde tutulmuş $(557 / 1162)^{49}$ bu olaydan kısa bir süre sonra Sâhibülmahzen Ebü'l-Fazl Yahyâ b. Ubeydullah b. Ca'fer de gözaltına alınarak İbnü'l-Müslime’nin evinde kalmış ve yerine vekâleten Ârızülceyş ${ }^{50}$ İbn Hamdûn tayin edilmiştir ${ }^{51}$. Yine Zilhicce 558 (Kasım 1163) tarihinde Nakîbünnükebâ ${ }^{52}$ İbnü'l-Abakî görevinden azledilerek İbnü'l-Müslime'nin evine getirilmiştir ${ }^{53}$.

İbnü'l-Gevzî, el-Muntazam, C XVIII, s. 152. İbnü'ş-Şemhal'in gözaltına alınmasıyla ilgili olarak kaynaklarda herhangi bir sebep zikredilmemekle birlikte, günümüz araştırmacılarından Hanne, İbnü'ş-Semhal'in hanımının önemli bir aileden gelmesinin onun tutuklanmasında etkili olabileceğini ileri sürmektedir. Bk. Eric Hanne, The Caliphate Revisited: The Abbasids of $11^{\text {th }}$ and $12^{\text {th }}$ Century Baghdad (doktora tezi), The University of Michigan, Near Eastern Studies, Michigan 1998, s. 379, dn. 36 .

50 İslâm tarihinin erken dönemlerinde ordunun idarî, malî ve hukukî işleriyle ilgilenmek üzere

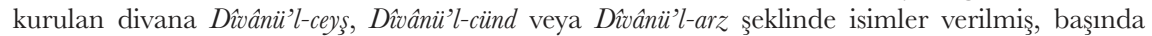
bulunan kişiye de sâhibü dî̀âni'l-ceyş, sâhibiu dîvani'l-arz, ânzzülceyş veya ânz denilmiştir. Abbâsîler'in erken dönemlerinde daha çok Dîvânü'l-ceys olarak isimlendirilen bu yapıyı Irak Büveyhîleri Türkler ve Deylemîler için ikiye ayırarak Dîvânü'l-Ceyșeyn olarak adlandırmışlar, başında bulunan kişiye de ârnz demişlerdir. Irak Büveyhîleri'nden sonra diğer İslâm devletlerinde bu divan daha çok Dîvanü'l-arz şeklinde yaygınlık kazanmaya başlamıştır. Geniş bilgi için bk. Fuat Köprülü, "Arz", İslâm Ansiklopedisi, C 1, Milli Eğitim Bakanlığı, İstanbul 1978, s. 657-660; Erdoğan Merçil, "Ârrz", İslâm Ansiklopedisi, C 3, Türkiye Diyanet Vakfi, İstanbul 1991, s. 359; Abdülazîz ed-Dûrî, "Divan", İslâm Ansiklopedisi, C 9, Türkiye Diyanet Vakfi, İstanbul 1994, s. 379; Aydın Taneri, "Divan (Büyük Selçuklular'da Divan)", İslâm Ansiklopedisi, C 9, Türkiye Diyanet Vakfi, İstanbul 1994; s. 384; Erdoğan Merçil, "Selçuklular (Selçuklular'da Devlet ve Teşkilat)", İslâm Ansiklopedisi, C 36, Türkiye Diyanet Vakfi, İstanbul 2009, s. 390.

51 İbnü'l-Cevzî, el-Muntazam, C XVIII, s. 155.

52 Abbâsîler döneminde Abbasoğulları (Hz. Peygamber'in amcası Abbâs'ın soyundan gelenler) ve Alioğulları (Hz. Ali ve Hz. Fatıma soyundan gelenler) ile ilgili bazı hizmetleri ifa etmek üzere merkezde nakîbü'l-ensâb adıverilen bir görevli tayin edilmiştir. Ancak zamanla bu uygulama yaygınlaşınca Hz. Ali ve Hz. Fatıma'nın soyundan gelen nakiblere Nakîbü't-Talibiyyin veya Nâkibü'l-Aleviyyîn, Hz. Peygamber'in amcasının soyundan gelen nakiblere ise Nakîbï'l-Abbâsiyyîn veya Nakîbü'l-Hâşsimiyyîn denilmiştir. Bu nakiblerin başında bulunanlara nakîbünnükebâ unvanı verilmiş ve bu kişiler halifenin menşuruyla tayin edilmiştir. Zaman zaman bu göreve getirilen kişiler siyasî ve idarî açıdan etkin bir rol oynamışlardır. Geniş bilgi için bk. Abdülkerim Özaydın, "Selçuklular Döneminde Nakîbü’n-Nukabâların Siyâsî, İdârî ve İçtimâî Hayattaki Rolleri: Tırâd b. Muhammed ve Oğlu Alî b. Tirâd el-Kureşî el-Hâşimî el-Abbâsî ez-Zeynebî Örneği”, Türkiye Tazarlar Birliği (TYB) Akademi: Dil Edebiyat ve Sosyal Bilimler Dergisi, 12 (2014), s. 101-114; Ş. Tufan Buzpınar, "Nakîbüleşrâf”, İslâm Ansiklopedisi, C 32, Türkiye Diyanet Vakfi, İstanbul 2006, s. 322-324.

53 İbnü'l-Cevzî, el-Muntazam, C XVIII, s. 156. Nakîbünnükebâ dışındaki kişilerin tutuklanmasıyla ilgili herhangi bir gerekçe sunmayan İbnü'l-Gevzî, İbnü’l-Abakî’nin Müsterşid döneminin önde gelen emîrlerinden ve aynı zamanda Basra'nın iktâını elinde bulunduran Mengüpars'la mektup- 
Üstâdârlığa atandıktan sonra divanların işleyişinde önemli bir nüfuz elde eden ve bu nüfuzunu devlet adamlarına yönelik uygulamalarda açıkça ortaya koymaktan çekinmeyen İbnü'l-Müslime'nin bu tavrını Vezir İbn Hübeyre'nin aile fertleriyle ilgili yaşanan hadiselerde de devam ettirmiş olması kuvvetle muhtemeldir. Nitekim İbn Hübeyre'nin vefatından sonra gözaltına alınan iki oğlu İzzüddîn ve Şerefüddîn’in mallarına el konulmuş ve bu kişilerin yanı sıra İbn Hübeyre’nin diğer vârisleri [geçimlerini temin etmek için] elbiselerini ve [değerli] eşyalarını satmak zorunda kalmıştır. Ailesine yapılanlar bunlarla sınırlı kalmayan İbn Hübeyre'nin kendi medresesine veya diğer yerlere vakfettiği kitaplar da satılmıştır ${ }^{54}$.

İbnü'l-Müslime'nin giderek artan nüfuzu Müstencid'i rahatsiz edecek düzeye ulaşmış ve muhtemelen halife bu sorunu çözmek amaciyla ${ }^{55}$ Bağdat'taki siyasî çevrelerle doğrudan bir irtibatı bulunmayan dönemin Vâsıt nâzırı (idareci/ müfettiş) İbnü'l-Beledî̀yi vezirliğe tayin etmiştir (4 Safer 563/19 Kasım 1167) ${ }^{56}$. Kâdılkudât, üstâdâr, saray görevlileri, ordu komutanları ve diğer pek çok kimsenin hazır bulunduğu görkemli bir merasimle vezirlik hil'‘atini giyen İbnü'l-Beledî, Şerefüddîn, Celâlülislâm, Muizzüddevle, Seyyidülvüzerâ ve Sadrü’ş-şark ve'l-garb gibi unvanlarla taltif edilmiştir ${ }^{57}$. Yukarıda da zikredildiği üzere vezirlik için en güçlü aday olmasına rağmen halife tarafindan tercih edilmeyen Üstâdâr İbnü'lMüslime, muhtemelen kendisi de böyle bir beklenti içinde olduğu için, yeni vezir için tertip edilen karşılama ve hil'at merasimine katılmak istememiştir. Hatta bunun için hazineye 5 bin dinar vermeyi taahhüt etmiş, ancak halifenin emriyle merasime katılmak zorunda kalmıştır ${ }^{58}$.

laşıp onu Bağdat’a gelmeye teşvik ettiği için tutuklandığını aktarmaktadır.

54 Sibt İbnü'l-Cevzî, Mir'âtiu'z-zamân, C XXI, s. 68.

55 Benzer bir yaklaşım için bk. Mackay, "Patronage and Power", s. 37; Hanne, The Caliphate Revisited, s. 389.

56 İbnü'l-Beledî Vâsıt'ta nâzırlık yaptığı sırada Hûzistân hâkimi Şümle (Şemle) Bağdat yakınlarındaki Mâhikî kalesini, yeğeni İbn Şenkâ da Basra ve Vâsıt'ı ele geçirmeye yönelik girişimlerde bulunmuştur. İbnü’l-Beledî ise Basra'nın iktâını elinde bulunduran Emîr Erkuş'la birlikte bu girişimi bertaraf etmek için büyük bir çaba sarfetmiştir. Bk. İbnü'l-Esîr, el-Kâmil, C XI, s. 328-329. İbnü'l-Beledî'nin bu çabalarının da etkisiyle halifeyle aralarında yakın bir dostluğun kurulduğunu belirten Azzâm, onun vezirliğe tayin edilmesinde bu dostluğun etkili olabileceğini imâ etmektedir. Bk. Azzâm, el-Vizâretiu'l-Abbâsiyye, s. 177-178.

57 İbnü'l-Cevzî, C XVIII, s. 176; İbnü'l-Esîr, el-Kâmil, C XI, s. 332; Zehebî, Târîh: sene 561-570, s. 11; Azzâm, el-Vizâretü'l-Abbâsiyye, s. 140.

58 Ebû Ca'fer Safiyyüddîn Muhammed b. Alî b. Tabatabâ İbnü't-Tiktakâ, el-Fahrî fi'l-âdâbi'ssultâniyye ve'd-düveli'l-İslâmiyye, Dâru Sâdır, Beyrut [ts.], s. 317. 
Vezirlik görevini üstlendikten sonra devletin malî işleriyle yakından ilgilenen İbnü'l-Beledî, Kûfe ile Bağdat arasında yer alan Hille'ye giderek buradaki [arazilerden elde edilen gelirlerle ilgili ?] durumu bizzat denetledi59 ${ }^{5}$, ayrıca Halife Müstencid'in emriyle Üstâdâr İbnü'l-Müslime ve ailesinin idarî açıdan nüfuzunun azaltılması için bazı tedbirler aldı. Şöyle ki, Muktefî döneminden itibaren Nehrü’lmelik'in ${ }^{60}$ âmilliğini yapan İbnü'l-Müslime'nin kardeşi Tâcüddîn'in görevine son vererek âmillik yaptığı süre zarfinda bu topraklardan elde ettiği gelirlerle ilgili kendisinden bir rapor istedi ve bu sayede devlete büyük bir gelir sağladı. Bununla da yetinmeyen İbnü'l-Beledî, birkaç yıl sonra İ̉nnü'l-Müslime'nin halasının oğlu İbnü's-Sîbî lakabıyla tanınan Muhammed b. Hüseyin ve kardeşinin ${ }^{61}$ gözaltına alınmasını emretti. Bimâristânın idaresinden sorumlu olan Muhammed b. Hüseyin’in kardeşi, yanında fazla/yanlış tartan bir tür ağırlık ölçüsü [dirhem gibi değerli şeyleri tartmaya yarayan] bulunduğu için veya bir başka sebepten dolayı elleri ve ayakları kesilerek öldürüldü. Ailesi ve yakın çevresi bu şekilde bir muameleye maruz kalan İbnü'l-Müslime ise büyük bir endişeye kapıldı ve bütün bunlar Vezir İbnü'l-Beledî ile arasında köklü bir düşmanlığın meydana gelmesine neden oldu ${ }^{62}$.

Üstâdâr İbnü’l-Müslime dışında dönemin etkili şahsiyetlerinden bir diğeri Müstencid'in memlüklerinden ${ }^{63}$ olan Emîr Kutbüddîn Kaymâz'dır. Sâbık vezir cak İbnü'l-Cevzî ve İmâdüddîn el-İsfahânî’nin verdiği bilgiye göre bu kişinin ismi Ebü’l-Muzaffer İzzüddevle Hüseyin b. Muhammed'dir ve Kûsân'ın âmilliğini yapmaktadır. Bk. İbnü'l-Cevzî, el-Muntazam, C XVIII, s. 188-189; İmâdüddîn el-İsfahânî, Harîdetii’l-kasr, G I, s. 185-186. Kûsân Vâsıt ile Nu'mâniyye (Bağdat'la Vâsıt'ın tam ortasında bulunan bir yerleşim yeridir.) arasında bulunan büyük bir köydür. Geniş bilgi için bk. Yâkût el-Hamevî, Mu'cemü'l-büldân, C IV, s. 413, C V, s. 294. Kaynaklarda bu iki kardeşin isimleriyle ilgili bir karışıklığın olduğu anlaşılmaktadır Nitekim bu duruma dikkat çeken Mackay, her hangi bir kaynağa işaret etmeksizin kardeşlerden büyük olanının ismini Fahrüddevle Ebû Abdullah Hasan b. Muhammed şeklinde zikretmektedir Bk. Mackay, "Patronage and Power", s. 38, dn. 1. Bu şahısların isimleriyle ilgili karışıklık küçük olanının göreviyle ilgili de geçerlidir. Zira İbnü'l-Esîr'in kayıtlarında bu kişinin bîmâristânın sorumlusu olduğu ifade edilirken, İbnü'l-Cevzî’nin verdiği bilgiye göre ise aynı kişi Kûsân'ın amilliğini yapmaktadır.

62 İbnü’l-Esîr, el-Kâmil, C XI, s. 332-333, 349, 361. Ayrıca bk. İbnü’t-Tıktakâ, el-Fahrî, s. 317

63 Esir veya köleler arasından seçilip özel eğitimden geçirildikten sonra hükümdarın muhafız birliğine alınan ve zamanla aristokrat bir sınıf oluşturan ücretli askerlere verilen bir isimdir. İslâm tarihinin erken dönemlerinden itibaren askerî hizmetlerde görev alan memlükler zaman zaman siyasî olarak iktidarı belirlemede etkin bir rol oynamışlardır. Geniş bilgi için bk. Süleyman Kızıl- 
İbn Hübeyre'nin vefatından sonraki olaylar sırasında nispeten geri planda kalan Emîr Kaymâz, özellikle Müstencid'in rahatsızlanması ve vefatıyla sonuçlanan hadiselerde Üstâdâr İbnü'l-Müslime ile birlikte etkin bir rol oynamıştır. İbnü’lEsîr'in verdiği bilgiye göre Müstencid, doktoru İbn Safiyye vasıtasıyla veziri İbnü'l-Beledî’ye haber göndererek Üstâdâr İbnü'l-Müslime ve Emîr Kaymâz'in yakalanmasını emretmiştir ${ }^{64}$. el-Kâmil'de yer alan rivayette tutuklama emrinin sebebiyle ilgili herhangi bir kayıt yer almamaktadır. Ancak Sıbt İbnü'l-Cevzî’nin aktardığı rivayete göre Müstencid'in rahatsızlığı sırasında Emîr Kaymâz'ın veliaht Ebû Muhammed Hasan'la (Müstazî-Biemrillâh) yazıştı̆̆ını öğrenen Vezir İbnü'lBeledî, durumu Müstencid'e haber vermiş, bunun üzerine halife her ikisinin de yakalanmasını emretmiştir ${ }^{65}$.

Olayların seyrine bakıldığında veliaht Ebû Muhammed'le sadece Emîr Kaymâz’’n değil İbnü'l-Müslime’nin de görüşmüş olması kuvvetle muhtemeldir. Dolayısıyla Müstencid sonrası iktidarın planlayıcısı konumunda bulunan İ̉nü'l-Müslime ve Emîr Kaymâz'in bu yöndeki faaliyetlerinden haberdar olan Müstencid'in, veziri İbnü'l-Beledî’ye haber göndererek bu iki şahsın tutuklanmasına karar verdiği anlaşılmaktadır. Ancak Müstencid'in bu tutuklama kararını doktoru İbn Safiyye vasıtasıyla Vezir İbnü'l-Beledî’ye ulaştırmak istemesi kendi sonunu hazırlamıştır. Şöyle ki, bir saray çalışanı olarak İbn Safiyye, haliyle Üstâdâr İbnü'l-Müslime'nin adamı olduğu için vezire ulaştırmak üzere aldığı halifenin yazılı emrini İbnü’lMüslime'ye getirmiş, bunun üzerine İbnü'l-Müslime, ona halifeye gitmesini ve emri vezire ulaştırdığını söylemesini istemiş̧ir. Daha sonra Emîr Kaymâz'la bir araya gelen İbnü'l-Müslime, halifenin kararını ona göstermiş ve birlikte Müstencid'i öldürmek için bir plan hazırlamıslar, hazırlanan planı uygulamak ise dönemin önde gelen askerlerinden Yezdan b. Kamâc ${ }^{66}$ ve Kaymâz el-Hamîdî̀ye düşmüştür. Müstencid'in yanına girerek onu zorla hamama götüren ve kapıyı kapatan Yezdan ve Kaymâz, zaten ateşli bir hastalı̆̆a yakalanan halifenin hararetten ölmesine sebep olmuşlardır ${ }^{67}$.

Müstencid'in öldüğüne dair haberler duyulmaya başlayınca Vezir İbnü'l-

\footnotetext{
toprak, "Memlük", İslâm Ansiklopedisi, C 28, Türkiye Diyanet Vakfi, İstanbul 2004, s. 87-90.

64 İbnü'l-Esîr, el-Kâmil, C XI, s. 360.

65 Sibt İbnü'l-Cevzî, Mir'âtü'z-zamân, C XXI, s. 168.

66 Yezdan daha önce Müstencid’in emriyle Hille'de ikâmet eden Benû Esed kabilesinin buradan sürülmesi için hazırlanan ordunun komutanlığını yapmıştır. Bk. İbnü'l-Esîr, el-Kâmil, C XI, s. 296.

67 İbnü'l-Esîr, el-Kâmil, C XI, s. 360-361; Sıbt İbnü'l-Cevzî, Mir'âtü'z-zamân, C XXI, s. 168.
} 
Beledî, komutanlar ve askerlerle birlikte harekete geçmiş, fakat halifenin ölüm haberinin gerçek olup olmadığını teyit edememiştir. Bu sırada İbnü’l-Müslime vezire haber göndererek halifenin rahatsızlı̆ının azaldığını ve giderek iyileştĭgini bildirmiştir. İbnü'l-Beledî ise Dârülhilâfe'ye askerlerle birlikte girerse kendisi hakkında olumsuz bir kanaat oluşacağından endişelenerek konağına dönmüş, yanındakiler de dağılmıştır. İbnü'l-Beledî ve yanındakilerin içeri girip kendilerini tutuklayacaklarından korkan İbnü'l-Müslime ve Kaymâz ise Dârülhilâfe'nin kapılarını kapatmışlar ve hemen akabinde Müstencid'in vefat ettiğini duyurmuşlardır ${ }^{68}$.

\section{Vezirliği}

\section{a. Emîr Kutbüddîn Kaymâz ile Mücadelesi}

Müstencid'in vefatından sonra Üstâdâr İbnü'l-Müslime ve Emîr Kaymâz, bazı şartlar öne sürerek Ebû Muhammed Hasan'ı Müstazî-Biemrillâh lakabıyla hilafet makamına geçirdiler. Tarihçiler tarafindan ismi Hasan olup da halifelik yetkilerini kullanması engellenen iki kişiden birisi (diğeri Hz. Hasan) olarak tavsif edilen Müstazî-Biemrillah, kendisine sunulan şartları kabul etmek durumunda kaldı. Bu şartlara göre İbnü’l-Müslime vezirliğe, oğlu Kemâlüddîn üstâdârlı̆̆a, Emîr Kaymâz da ordu komutanlığına (emîrülceyş) tayin edildi. Babasının öldüğü gün hanedan üyelerinin biatını (el-bey'atü’l-hâssa) kabul eden Müstazî, ertesi gün Tâc sarayında halkın biatını (el-bey'atü’l-âmme) aldı (10 Rebiülâhir 566 / 21 Aralık $1170)^{69}$.

Diğer taraftan bütün bu olup bitenleri öğrenince Müstencid’in öldüğü gün askerlerle birlikte saraya girmediği için büyük bir pişmanlık duyan İbnü’l-Beledî, yeni halifeye biat etmesi için kendisine yapılan davete icabet ederek saraya gitti, ancak gelir gelmez öldürüldü, cesedi ise Dicle nehrine atıldı (Rebiülevvel 566/Aralık 1170). Vezirliği üç yll bir ay ${ }^{70}$ kadar devam eden İbnü'l-Beledî’nin ölümünden sonra evinde bulunan her şeye el konuldu. Bu sirada onun halifeyle yaptıkları yazışmalara muttali olan İbnü'l-Müslime ve Emîr Kaymâz, kendilerini

68 İbnü'l-Esîr, el-Kâmil, C XI, s. 361.

69 İbnü'l-Cevzî, el-Muntazam, C XVIII, s. 190-191; İbnü'l-Esîr, el-Kâmil, C XI, s. 361.

70 Zehebî, İbnü’l-Beledî’nin altı yıl vezirlik yaptığını aktarmaktadır. Bk. Zehebî, Târîh: sene 561-570, s. 243. Ancak İbnü'l-Beledî’nin 4 Safer 563 (19 Kasım 1167) tarihinde vezirliğe tayin edildiği (bk. İbnü'l-Gevzî, el-Muntazam, XVIII, s. 176) göz önünde bulundurulursa Zehebî’nin verdiği sürenin yanlış olduğu anlaşılmaktadır. Muhtemelen Zehebî, bu altı yıllık süreye Kâdılkudât Ebü’l-Berekât Ca‘fer es-Sekâfî’nin üç yıl devam eden naîbülvezirlik görevini de dâhil etmiş olmalıdır. 
tutuklatmak isteyen Müstencid'e karşı İbnü'l-Beledî’nin af talebinde bulunduğunu öğrenince onun ölümünden dolayı pişman oldukları söylenmektedir ${ }^{71}$.

Rivayetin son kısmındaki bilgilerle ilgili bir kaç hususa işaret edilmelidir. Yukarıda da zikredildiği üzere Halife Müstencid, Vezir İbnü'l-Beledî’ye bir mektup göndererek İbnü'l-Müslime ve Emîr Kaymâz'ın gözaltına alınmasını istemişti. Ancak bu mektup vezire ulaşmadan İbnü'l-Müslime'nin eline geçmiş, bundan dolayı İbnü'lBeledî, halifenin İbnü'l-Müslime ve Emîr Kaymâz'ın tutuklanmasını istediğini öğrenememişti. Dolayısıyla İbnü’l-Beledî’nin İbnü’l-Müslime ve Emîr Kaymâz için halifeden af dilediğine dair evinde bulunduğu iddia edilen yazışmalarla ilgili bilgilerin teyide muhtaç olduğu veya bir başka hadiseye işaret etme ihtimalinin bulunduğu belirtilmelidir.

Müstazî’nin tahta çıkmasından hemen sonra İbnü'l-Müslime vezir olarak görevlendirilmesine rağmen Müstencid’in vefatı münasebetiyle tertip edilen taziye merasiminden dolayı kendisi için bir tören düzenlenememişti. Üç gün devam eden bu merasimde taziyeleri kabul eden İbnü'l-Müslime'ye 20 Cemâziyelevvel 566 (29 Ocak 1171) tarihinde Adudüddîn lakabıyla birlikte hil'at verildi. Ardından kâdılkudât, komutanlar, hâcibler, kâtipler ve diğger görevlilerle birlikte evine kadar giden İbnü'l-Müslime, burada kendisine sunulan tebrikleri kabul etti ${ }^{72}$. Ayrıca cami, medrese, ribât ve meşhedlerde ${ }^{73}$ kalanlara çokça buğday ve altın dağıttı ${ }^{74}$.

İbnü'l-Müslime’nin birinci vezirliği, kuvvetle muhtemel birlikte hareket ettikleri Emîr Kaymâz’la arasının açılması sebebiyle nispeten kısa sürdü ve 10 Şevval 567 (5 Haziran 1172) tarihinde sona erdi. Müstazî’nin İbnü’l-Müslime’yi görevinden azlettiğine dair mektubu kendisine getiren Hâdim ${ }^{75}$ Necâh, ondan vezirlik alameti

71 İbnü'l-Esîr, el-Kâmil, C XI, s. 361-362. Ayrica bk. İbnü’l-Cevzî, el-Muntazam, C XVIII, s. 191; Sıbt İbnü'l-Cevzî, Mir'âtü'z-zamân, C XXI, s. 169; İbn Hallikân, Vefeyât, C IV, s. 470; İbnü't-Tıktakâ, el-Fahrî, s. 318; Zehebî, Târîh: sene 561-570, s. 243.

72 İbnü'l-Cevzî, el-Muntazam, C XVIII, s. 191-192; İbnü’n-Dübeysî, Zeylü Târîhi Medîneti’s-selâm, C I, s. 372.

73 Irak'ın Necef, Kerbelâ, Samerrâ ve Kâzımeyn gibi yerleşim yerlerinde Hz. Peygamber'in soyundan gelen kişilerin kabirlerinin bulunduğu yerlerdir. Ayrıntılı bilgi için bk. Avni İlhan, "Atebât", İslâm Ansiklopedisi, G 4, Türkiye Diyanet Vakfi, İstanbul 1991, s. 49-50; Mustafa Öz, "Meşhed", Islâm Ansiklopedisi, C 29, Türkiye Diyanet Vakfi, İstanbul 2004, s. 362-363.

74 İbnü't-Tıktakâ, el-Fahrî, s. 319.

75 Saraydaki çeşitli hizmetlerde kullanılmak üzere istihdam edilen hâdimler zaman zaman idarî ve askerî görevler de üstlenmişlerdir. Muktedir-Billâh döneminde Hâdim Mürşid ve Hâdim Mûnis, Kâhir-Billâh döneminde ise Hâdim Sâbûr vezir ve diğer üst düzey bazı memurların gözaltına alınmasında görevlendirilmişlerdir. Bk. Ebû Alî Ahmed b. Muhammed İbn Miskeveyh, Kitâbü 
sayılan izârını ${ }^{76}$ çıkarmasını ve divitini kapatmasını istedi. İbnü'l-Müslime'nin vezirlikten azledilmesiyle oğlu Kemâlüddîn'in de üstâdârlık görevine son verildi ${ }^{77}$.

Kaynaklarda İbnü'l-Müslime'nin görevinden azledilmesiyle ilgili farklı rivayetler aktarılmıştır. Sıbt İbnü’l-Cevzî’nin verdiği bilgiye göre İbnü'l-Müslime, zorba ve zalim olmasıyla bilinen oğlu Üstâdâr Kemâlüddîn’in yaptıklarından dolayı görevinden azledilmiştir. Hâdim Sandal el-Muktefevî tarafindan gözaltına alınan Kemâlüddîn'in evinde bulunan mallara da el konulmuştur ${ }^{78}$.

Diğer taraftan Müstazî̀nin tahta çıkmasıyla ordu komutanlı̆̆ına tayin edilen Emîr Kaymâz, sahip olduğu yetkilerin yanı sıra halifeyle kurduğu yakın ilişkiler sayesinde dönemin en önemli şahsiyetlerinden birisi haline gelmiştir. Nitekim İbnü'l-Cevzînnin verdiği bilgiye göre insanların kendisine ulaşması gittikçe zorlaşan Müstazî̀nin yanına hizmetçiler ve Emîr Kaymâz'ın dışında kimse giremez olmuştur ${ }^{79}$. Ayrıca ordu komutanı olmasının da etkisiyle devlet idaresinde pek çok meseleye müdahale eder hale gelen Emîr Kaymâz, halife tarafindan

Tecâribi'l-Ümem (nşr. Henry Frederick Amedroz \& David Samuel Margoliouth), I-II, Matba'atü'ş-Şeriketi't-Temeddün, Kahire 1914, G I, s. 209, 272; İbnü'l-Cevzî, el-Muntazam, C XIII, s. 82, 89. Devlet memurlarının gözaltına alınması ve sorgulanmasının dışında hâdimler orduda da görev yapmışlardır. Örneğin Muktedir döneminde Hâdim Mûnis halife tarafindan Doğu Roma'ya karşı savaşmak üzere Tarsus'a gönderilmiştir. Ayrıca Mısır'ın Fâtımîler'den geri alınmasında göstermiş olduğu başarıdan dolayı Muktedir tarafindan "el-Muzaffer" lakabıyla taltif edilmiştir. Yine bir başka örnekte, Doğu Roma'ya ait bazı bölgelerin fethine katılan Hâdim Büşr'in elde edilen başarılarla ilgili gönderdiği mektup Bağdat'ta minberlerden okunmuştur. Bk. İbnü'l-Gevzî, el-Muntazam, C XIII, s. 82, 150. Hâdim Mûnis'in hayatı, siyasî ve askerî faaliyetleriyle ilgili geniş bilgi için bk. Sâim Yılmaz, "Abbâsîler Dönemi Türk Komutanlarından Mûnis el-Muzaffer'in (ö. 321 /933) Hayatı ve Askerî Görevleri”, Çukurova Üniversitesi İlahiyat Fakültesi Dergisi, 7 (2007), s. 123 156; a. mlf. "Türk Komutanlardan Mûnis el-Muzaffer'in (ö. 321/933) Abbâsî Tarihindeki Siyasî Etkinliği”, Dinî Araşttrmalar, 30 (2008), s. 121-152.

76 Geleneksel olarak izâr (veya mi'zer) erkeklerin vücutlarını göbeklerinden dizlerinin bir karış altına kadar olan kısmını kapatmak için kullandıkları örtüye verilen isimdir. Hamamlarda bele sarılan peştamal ile erkek ve kadınların iç gömleklerine de izâr denilmiştir. Ancak izâr bazı durumlarda elbisenin üstüne giyilen ve bir tür dış elbise anlamında da kullanılmıştır. Bk. Nebi Bozkurt, "Kıyafet”, İslâm Ansiklopedisi, C 25, Türkiye Diyanet Vakfi, İstanbul 2002, s. 509. Abbâsîler döneminde izâr zaman zaman resmî bir göreve atanan kişiye hil'at olarak da takdim edilmiştir. Nitekim Halife Mutî‘-Lillâh (334-364/946-974) Büveyhî emîri İzzüddevle Bahtiyâr'mn (356-367/967-978) vezirliğine tayin edilen Muhammed b. Bakıyye'ye (ö. 367/977-978) hil'at olarak altın veya gümüş iple işlenmiş bir izâr vermiştir. Bk. Ebü'l-Hüseyin Hilâl b. Muhassin es- Sâbî, Rüsûmü dâri'l-hilâfe (nşr. Mîhâîl Avvâd), Dârü’r-Râidi'l-Arabî, Beyrut 1406/1986, s. 98; Salâh Hüseyin el-Ubeydî, el-Melâbisü'l-Arabiyyetü'l-Íslâmiyye fi'l-Asri'l-'Abbâsî, Dârü'r-Reşîd li'n-Neşr, Bağdat 1980, s. 183.

77 İbnü'l-Gevzî, el-Muntazam, C XVIII, s. 197.

78 Sibt İbnü'l-Cevzî, Mir'âtü'z-zamân, C XXI, s. 173.

79 İbnü'l-Cevzî, el-Muntazam, C XVIII, s. 192-193. Ayrıca bk. Safedî, el-Vâfî, C XII, s. 193.

Belleten, Ağustos 2021, Cilt: 85/Say1: 303; 423-461 
Melikülarab lakabıyla taltif edilmiş ve kendisine Ürdün ve Hille'nin iktan ile altından mamul bazı hediyeler verilmiştir ${ }^{80}$. Bütün bunlar Emîr Kaymâz'ı siyasî ve ekonomik açıdan İbnü'l-Müslime ile rekabet edebilecek bir konuma getirmiştir. Bu noktada detayları hakkında herhangi bir bilgi aktarmamakla birlikte Zehebî, Emîr Kaymâz'la Vezir İbnü'l-Müslime'nin arasında bir takım anlaşmazlıkların yaşandığını ve ikisinin birbirinden nefret ettiğini söylemektedir ${ }^{81}$. Konuyla ilgili nispeten daha kesin ifadelere yer veren İbnü'l-Esîr ise Emîr Kaymâz'm Müstazî'den İbnü'l-Müslime'yi azletmesini istediğini, Müstazî’nin de Kaymâz’’n devlet içindeki gücünden dolayı onun görüşüne muhalif hareket etmeyip İbnü’lMüslime'yi görevinden aldığını aktarmaktadır ${ }^{22}$. İbnü’l-Müslime'yi görevinden azlettirmekle yetinmeyen Emîr Kaymâz, halkı ve emrindeki askerleri vezirin konağını yağmalamaya teşvik etmiş, hatta haremine varıncaya kadar bütün mallarını talan etmiştir. Kaymâz'ın davranışlarından büyük bir rahatsızlık duyan Müstazî ise el konulan malların İbnü’l-Müslime'ye iade edilmesini istemiş, ayrıca Hâdim Necâh'ı İbnü'l-Müslime'ye göndererek yaşananlardan dolayı kendisini teskin etmesini istemiştir ${ }^{83}$.

Konuyla ilgili Sıbt İbnü'l-Cevzî’nin aktardığı rivayete bakılacak olursa ahlakî açıdan zayıf bir kişiliğe sahip olan Üstâdâr Kemâlüddîn’in bu özelliklerinden dolayı babası İbnü'l-Müslime'nin vezirlikten azledildiğini söylemek pek mümkün değildir. Oğlu Kemâlüddîn'in görevinden alınmasına gelince, İbnü'l-Müslime’nin azlinden sonra Kemâlüddîn'in halifeyle yakın bir ilişki içerisinde olmasını gerektiren bir mevkide (üstâdârlıkta) kalmasının bir anlamı yoktur ${ }^{84}$. Yani Kemâlüddîn üstâdârlık görevini devam ettirmiş olsaydı bile hâmisini kaybeden birisi olarak onun halifenin yakınında bulunmasının bir önemi kalmayacaktı. Dolayısıyla İbnü'lMüslime vezirlikten azledilince Kemâlüddîn de üstâdârlık görevinden alınmıştır. Bu noktada İbnü'l-Müslime'nin gözden düşmesinde oğlu Kemâlüddîn'in kötü karakterli birisi olmasından ziyade, Emîr Kaymâz'ın aleyhteki girişimlerinin daha etkili olduğu anlaşılmaktadır. Nitekim günümüz araştırmacılarından Azzâm da benzer bir hususa işaret ederek Emîr Kaymâz'ın etkisiyle Müstazînnin böyle bir karar verdiğini belirtmektedir ${ }^{85}$.

80 Cemâleddin Muhammed b. Sâlim b. Vâsıl, Müferricü’-kürûb fỉ ahbârî mülûki Benî Eyyûb (nşr. Cemâleddin eş-Şeyyâl), I-III, Kahire 1953-60, C II, s. 87.

81 Zehebî, Siyeru a 'lâmi’n-nübelâ', C XXI, s. 76

82 İbnü'l-Esîr, el-Kâmil, C XI, s. 371 . Ayrıca bk. İbn Vâsıl, Müferricü'l-kürûb, C II, s. 87.

83 İbn Vâsıl, Müferricü'l-kürûb, C II, s. 87.

84 Mackay, "Patronage and Power", s. 40-41.

85 Azzâm, el-Vizâretü'l-Abbâsiyye, s. 181. 
İbnü'l-Müslime'nin görevinden alınmasından sonra yerine hemen bir atama yapmayan Müstazî, Sâhibülmahzen Ebü'l-Fazl Yahyâ b. Ca'fer'i nâibülvezîr olarak görevlendirmiş (12 Şevvâl 567/7 Haziran 1172) ${ }^{86}$ Hâdim Sandal el-Muktefevî̀yi de üstâdârlı̆̆a tayin etmiştir ${ }^{87}$.

Kaynaklarda vezirlikten azledildikten sonra siyasî hadiselerin içinde yer aldığına dair bir kayıt bulunmayan İbnü'l-Müslime anlaşıldığı kadarıyla bu süreçte nispeten sakin bir hayat yaşamıştır. Bununla birlikte yaklaşık üç ylldır nâibülvezîrlik görevini sürdüren Sâhibülmahzen Ebü'l-Fazl Yahyâ'nın 19 Rebiülevvel 570 (18 Ekim 1174) tarihindeki $^{88}$ vefatiyla birlikte tekrar vezirliğe atanması gündeme gelmiş, ancak yine Emîr Kaymâz'ın karşı çımasıyla bu göreve tayin edilmemiştiir ${ }^{89}$. Şöyle ki, İbnü'l-Müslime'nin vezirlikten azledilmesinde önemli bir rol oynayan Emîr Kaymâz, Müstazî’nin bu yönde bir karar verdiğini duyunca Bâbünnûbî ve Bâbülâmme kapılarını kapattırarak Dârülhilâfe'yi kuşatma altına aldı. Müstazî ise İbnü'l-Müslime'yi vezirliğe tayin etmeyeceğine dair söz verdi. Ancak tekrar göreve dönerse İbnü'l-Müslime’nin kendisini öldüreceğinden korkan Emîr Kaymâz, bu konuda ikna olmak için İbnü'l-Müslime ve ailesinin Bağdat'tan çıarılmasını istedi. Kaymâz'ın kendisine zarar vereceğinden endişe eden İbnü'l-Müslime ise şehirden ayrılmayı kabul etmemekle birlikte Dârülhilâfe'den ayrılarak şehirde bir başka yere gitmeye razı oldu, ancak bunun da emniyet altına alınmasını istedi. Bunun üzerine Kaymâz, mazul vezirin herhangi bir takibata maruz kalmayacağına

İbnü'l-Cevzî, el-Muntazam, G XVIII, s. 197; Sıbt İbnü'l-Cevzî, Mir'âtü'z-zamân, C XXI, s. 234.

İbnü'l-Esîr, el-Kâmil, C XI, 371. Hâdim Sandal yaklaşık üç yıl sonra üstâdârlık görevinden azledilmiştir. Bk. Sıbt İbnü'l-Cevzî, Mir'âtü'z-zamân, C XI, s. 235.

İbnü'l-Cevzî, el-Muntazam, C XVIII, s. 217.

Günümüz araştırmacılarından Azzâm, Abdurrahman b. İbrahim b. Sunbut el-Erbilî, Safedî ve Muhammed b. Şâkir el-Kütübî'ye dayanarak Ebü'l-Fazl Yahyâ b. Ca'fer'den sonra Muhammed el-Enbârî’nin nâibülvezîr olarak görevlendirildiğini öne sürmüş, ancak bu dönemde vezirlik ve nâibülvezîrlik yapanların isimlerini verdiği listede Enbârî’nin ismini zikretmemiştir. Bk. Azzâm, el-Vizâretü'l-Abbâsiyye, s. 182, 204. Erbilî’nin eserinde Azzâm'ın iddia ettiği şekilde bir bilgi yer almamaktadır. Bk. Abdurrahman b. İbrahim b. Sunbut el-Erbilî, Hulâsatüz-zehebi'l-mesbûk muhtasar min Siyeri'l-mülûk (nşr. Mekkî es-Seyyid Câsim), Mektebetü’l-Müsennâ, Bağdat [ts.], s. 279-280. Safedî ve Muhammed b. Şâkir el-Kütübî’nin eserlerinde ise Muhammed el-Enbârî’nin nâibülvezîr değil vezir olduğu zikredilmektedir. Bk. Safedî, el-Vâfî, C XII, s. 193; Muhammed b. Şâkir el-Kütübî, el-Fevâtü'l-Vefeyât ve'z-zeyl 'aleyhâ (nşr. İhsan Abbas), I-V, Beyrut 1973-1974, C I, s. 371 372. Ancak döneme yakın kaynaklarda Enbârî’nin böyle bir görev üstlendiğine dair herhangi bir kayıt bulunmamaktadır. Bu durum Safedî ve Kütübî’nin verdiği bilgilerin teyide muhtaç olduğunu göstermesinin yanında, Ebü'l-Fazl'ın vefatıyla (19 Rebîulevvel 570/18 Ekim 1174) İbnü'lMüslime’nin ikinci kez vezirliğe atanması (23 Zilkade 570/15 Haziran 1175) arasında geçen yaklaşık dokuz aylık süre zarfinda vezirliği kimin üstlendiğini tespit etmeyi de zorlaştırmaktadır. 
dair söz verince, İbnü’l-Müslime ve ailesi dönemin önde gelen şahsiyetlerinden Şeyhüşşüyûh ${ }^{90}$ Sadrüddîn Ebü'l-Kâsım Abdürrahîm b. İsmâîl (ö. 580/1184) ve Fahrüddevle Ebü'l-Muzaffer Hasan b. Hibetullah b. el-Muttalib’in (ö. 578/1183) ${ }^{92}$ eşliğinde Dârülhilâfe'den ayrılarak önce Ebû Sa'd es-Sûfî ribâtına gitti, birkaç gün sonra da Bağdat'm batı yakasına geçti. Yaklaşık bir ay sonra tekrar kendi evine döndü (7 Cemâziyelâhir 570/3 Ocak 1175) ${ }^{93}$. Emîr Kaymâz ise bu meseleyle ilgili ortaya koyduğu tavırdan dolayı Müstazî̀den özür diledi9 ${ }^{94}$.

Bu olaydan bir kaç ay sonra (Şaban 570/Mart 1175) dönemin bir başka etkili şahsiyeti Sâhibülmahzen Zahîrüddîn Ebû Bekir Mansûr b. Nasr İbnü'l-Attâr'la ${ }^{95}$ yaşadığı çekişme sebebiyle tamamen gözden düşen Emîr Kaymâz, Bağdat'tan kaçmak durumunda kaldı. Kaymâz'la Sâhibülmahzen İbnü’l-Attâr'ın arasının açılmasına yol açan olaylar önde gelen komutanlardan ve aynı zamanda Kaymâz’ın eniştesi olan Emîr Tutâmış'ın Garrâf ${ }^{96}$ halkı üzerine bir ordu göndermesiyle başlamıstır. Askerlerin zulme varan davranışlarından dolayı Garrâf halkından

90 Şeyhüşşüyûh hangâh, zâviye ve ribâtların idaresinden sorumlu sûfî ve âlimlerle fütüvvet teşkilâtının en üst makamında bulunan kimselere verilen unvandır. Kelimenin anlamı ve müessese olarak ortaya çıkışıyla ilgili geniş bilgi için bk. Nathan Hofer, "The Origins and Development of the Office of the "Chief Sufi" in Egypt, 1173-1325", Journal of Sufi Studies, 3 (2014), s. 1-37; Harun Yılmaz, "Meşîhatüşşüyûh’un Doğuşu ve Mısır'da İki Hankah: Sa‘îdü’s-Sü‘adâ ve Siryâkûs" Tasavvuf İlmî ve Akademik Araştırma Dergisi, 34 (2014), s. 1-21; a. mlf. "Şeyhüşşüyûh", İslam Ansiklopedisi, C Ek-2, Türkiye Diyanet Vakfi, İstanbul 2019, s. 562-563.

91 Hayatı hakkında bk. İbnü'l-Esîr, el-Kâmil, C XI, s. 509; Zehebî, Târîh: sene 571-580, s. 307-308.

92 Hayatı hakkında bk. İbnü'l-Esîr, el-Kâmil, C XI, s. 491; Zehebî, Târîh: sene 571-580, s. 256-257.

93 İbnü'l-Cevzî, el-Muntazam, C XVIII, s. 212-213, 217; İbnü'l-Esîr, el-Kâmil, C XI, s. 409-410. Ayrıca bk. Sıbt İbnül-Cevzî, Mir'âtü'z-zamân, C XXI, s. 225; Zehebî, Târîh: sene 561-570, s. 60.

94 İbnü'l-Cevzî, el-Muntazam, C XVIII, s. 213.

95 Müstazî döneminde Ebü'l-Fazl Yahyâ b. Ca'fer ve İbnü'l-Attâr'in sâhibülmahzen olarak görev yaptıkları hemen bütün kaynaklarda zikredilmektedir. Ancak mevcut bilgiler doğrultusunda bu göreve hangisinin önce atandığına dair kesin bir şey söylemek pek mümkün görünmemektedir. Ancak Ebü'l-Fazl'ın 567 (1172) yılında nâibülvezîrlik görevine atandı̆ğ dikkate alınırsa İbnü'lAttâr'ın bu tarihten sonra beytülmâlin idaresini üstlendiği düşünülebilir. Nitekim İbnü'l-Esîr'in eserindeki bilgiler de Ebü'l-Fazl'ın vefat ettiği sırada İbnü'l-Attâr'ın sâhibülmahzen olarak görev yaptığını söylememize imkân tanımaktadır. Bk. İbnü'l-Esîr, el-Kâmil, C XI, s. 424, 426. Olayların seyrinden anlaşıldığı kadarıyla İbnü'l-Attâr, nâibülvezîrlik görevini devam ettiren Sâhibülmahzen Ebü'l-Fazl Yahyâ'nın vefatından sonra etkinliğini arttırmış, İbnü'l-Müslime'nin öldürülmesinden sonra nâibülvezîrliğe atanınca idarî açıdan hemen hemen en güçlü şahıs haline gelmiştir. Bk. İbnü'l-Esîr, el-Kâmil, C XI, s. 459. Nitekim Zehebî onun bu yönüne işaret ederek İbnü'l-Attâr'ın [nâibülvezîr olduktan sonra] devlet kademesinde istediği kişiyi görevlendirdiğini veya azlettiğini söylemektedir. Bk. Zehebî, Siyeru a 'lâmi'n-nübelâ', C XXI, s. 84-85.

96 Garrâf, Vâsıt ile Basra arasında bulunan büyük bir nehrin adıdır. Nehir boyunca pek çok yerleşim yeri bulunmaktadır. Bk. Yâkût el-Hamevî, Mu'cemü'l-büldân, C IV, s. 190. 
bazı kişilerin Bağdat'a gelmesiyle büyük bir infial yaşanmış, buna rağmen Kaymâz ve Tutâmış geri adım atmamışır. Bunun üzerine İbnü'l-Attâr'la aralarında bir anlaşmazlık ortaya çıkmıştır. Her ne kadar halifenin tavassutuyla İbnü’l-Attâr ve Kaymâz arasında kısmî bir barış sağlanmış olsa da, kısa bir süre sonra Kaymâz'ın emriyle İbnü'l-Attâr'n evi ateşe verilmiştir. Bununla da yetinmeyen Kaymâz, İbnü'l-Attâr'n Darülhilâfe'de olduğunu düşünerek kendisine destek olan bazı askerlerle birlikte saraya doğru harekete geçmiştir. Bunun üzerine sarayın çatısına çıan Müstazî, Kaymâz'ın evinin ve mallarının mubah olduğunu söyleyerek insanları ona karşı kışkırtmıştır. Olayların bundan sonraki safhasında evi ve malları yağmalanan Kaymâz, önce Hille'ye oradan da Musul'a kaçmak zorunda kalmış, fakat yolda ölmüştür ${ }^{97}$.

Kaymâz ve Sâhibülmahzen İbnü'l-Attâr arasındaki anlaşmazlığın en önemli sebebi, siyasî ve ekonomik açıdan gücünün zirvesinde bulunan Kaymâz'ın fütursuzca yaptı̆̆ı hareketlerin İbnü'l-Attâr tarafindan onaylanmamasıdır. Bu noktada Kaymâz ve Tutâmış'in haddi aşan davranışlar sergilemelerine rağmen bazı kaynakların, Müstazî’nin bu iki şahsın davranışlarına engel olamayacak kadar zaylf olduğunu söylemesi dikkat çekmektedir ${ }^{98}$. Bu durum İbnü'l-Attâr'ın tavrının Kaymâz tarafindan ciddi bir tehdit olarak algilandığını gösterebilir.

\section{b. Halife Müstazî ile Arasının Açılması ve Öldürülmesi}

Kaymâz’ı ölümüyle İbnü'l-Müslime'nin vezirliğe atanmasının önündeki büyük engel de ortadan kalkmış oldu. Nitekim onun Bağdat'tan kaçmasından kısa bir süre sonra Müstazî, İbnü'l-Müslime'yi ikinci kez vezirliğe tayin etti (23 Zilkade 570/15 Haziran 1175) ${ }^{99}$. Bu süreçte İbnü'l-Attâr yeniden sâhibülmahzen olarak görevlendirilirken ${ }^{100}$ diğer görevlerde ise bazı değişiklikler yaşandı. Daha önce İbnü'l-Müslime'nin oğlu Kemâlüddîn'in üstâdârlık görevinden azledilmesiyle onun yerine atanan Hâdim Sandal tutuklanarak üstâdârlıktan alındı, yerine İbnü's-Sâhib lakabıyla meşhur olan Ebü'l-Fazl Hibetullah b. Alî atandı ${ }^{101}$. Ayrıca makamının gerektirdiği ciddiyetten uzak olduğu gerekçesiyle hâciblik görevinden

97 İbnü'l-Esîr, el-Kâmil, C XI, s. 424-425. Ayrıca bk. İbnü'l-Cevzî, el-Muntazam, C XVIII, s. 215; Sıbt İbnü'l-Cevzî, Mir'âtii'z-zamân, C XXI, s. 226.

98 İbnü'l-Esîr, el-Kâmil, C XI, s. 424; Sıbt İbnü'l-Gevzî, Mir'âtü'z-zamân, C XXI, s. 225.

99 İbnü'l-Cevzî, el-Muntazam, C XVIII, s. 215; İbnü’l-Esîr, el-Kâmil, C XI, s. 426; Sibt İbnü'l-Cevzî, Mir'âtü'z-zamân, C XXI, s. 227.

100 İbnü'l-Gevzî, el-Muntazam, C XVIII, s. 222.

101 İbnü’l-Cevzî, el-Muntazam, C XVIII, s. 218; İbnü'l-Esîr, el-Kâmil, C XI, s. 434. 
azledilen Ebû Tâlib Nasr b. Alî en-Nâkıd'ın (İbnü’n-Nâkıd) yerine ise İbnü'lMuavvic getirildi ${ }^{102}$.

İkinci kez vezirliğe tayin edilen İbnü’l-Müslime kısa süren birinci vezirliğiyle kıyaslandığında bu dönemde idarî açıdan daha aktif bir rol oynamıştır. Şöyle ki, Irak Selçukluları'nın Hûzistân emîri Şümle'nin ${ }^{103}$ yanında bulunan III. Melikşah b. Sultan Mahmûd'un (547-548/1152-1153) oğlu el-Bendeniceyn'e ${ }^{104}$ büyük bir saldırı düzenleyince, İbnü'l-Müslime, Hac Emîri ${ }^{105}$ Tâştekîn ve Guzoğlu gibi Vâsıt ve Hille'den gelen komutanlarla birlikte harekete geçmiştir. Abbâsî ordusunun kendi üzerine geldiğini haber alan Melikşah’ın oğlu Irak topraklarından ayrılmak zorunda kalmıştır ${ }^{106}$.

Askerî faaliyetlerin dışında zaman zaman başta Halife Müstazî olmak üzere devlet ricaliyle âlimlerin katıldığı büyük davetler tertip eden ${ }^{107}$ İbnü’l-Müslime bu sayede bir taraftan idarî açıdan zayıflamış olan etkinliğini arttırmaya diğer taraftan halifenin kendisine olan güvenini yeniden kazanmaya çalıştı̆̆ı söylenebilir. Ancak bütün gayretlerine rağmen Halife Müstazî ile arası açılmıştır. Kaynaklar

102 İbnü'l-Cevzî, el-Muntazam, C XVIII, s. 221; İbnü’l-Esîr, el-Kâmil, C XI, s. 433.

103 Irak Selçuklu Sultanı Mahmûd b. Muhammed Tapar (511-525/1118-1131) döneminde Hûzistân'ın yönetimini üstlenen Şümle, özellikle VI. (XII.) yüzyllın ikinci yarısından itibaren Luristan’ı da hâkimiyeti altına alarak Hûzistân ve çevresini kapsayan yarı bağımsız bir emîrlik kurmuştur. Irak Selçuklu sultanları Muhammed b. Mahmûd ve III. Melikşah (547-548/1152-1153) arasında meydana gelen taht mücadelelerine de müdahele eden Şümle çıarları doğrultusunda sık sık saf değiştirmiştir. Sonraki yıllarda Hûzistân'daki hâkimiyetini pekiştirmeye çalışan Şümle, Türkmen aşiretleriyle girdiği savaşta öldürülmüştür. Şümle'den sonra onun soyundan gelenler Hûzistân'a hâkim olmaya devam etmişler, ancak Nâsır-Lidînillah (575-622/1180-1225) döneminde söz konusu bölgenin hâkimiyeti Abbâsî halifeliğine geçmiştir. Şümle'nin hayatı ve faaliyetleriyle ilgili geniş bilgi için bk. Qıyas Şükürov, "Şümle", İslâm Ansiklopedisi, C Ek-2, Türkiye Diyanet Vakfi, Istanbul 2019, s. 565-566.

104 Nehrevan tarafinda Bağdat'ın meşhur idarî bölgelerinden birisidir. Bk. Yâkût el-Hamevî, $M u^{\prime} c e^{-}$ mü'l-büldân, C I, s. 499.

105 Abbâsîler’in erken döneminde hanedan ailesinden birisinin üstlendiği bu görev Irak Büveyhîleri’nin Bağdat'a hâkim olmasıyla Alioğulları'nın nakîbine (nakîbü’l-Aleviyyîn) verilmeye başlamıştır. Selçuklu Sultanı Tuğrul Bey'in Bağdat'taki Büveyhî varlığını sona erdirmesinden sonra bu göreve Emîr Ebû Mansûr Kutluğ isminde bir komutan tayin edilmiştir. Muhtemelen bu uygulama, Emîr Taştekîn örneğinde olduğu üzere, sonraki dönemlerde de devam etmiştir. Hac emîrliğine asker kökenli kişilerin tayin edilmesinde Abbâsîler'in merkezî otoritesinin zayıflamasından dolayı hac yollarındaki güvenliğin tehlikeye düşmesinin etkili olduğu söylenmektedir. Geniş bilgi için bk. Münir Atalar, "Emîr-i Hac", İslâm Ansiklopedisi, C 11, Türkiye Diyanet Vakfi, İstanbul 1995, s. 131-133.

106 İbnü'l-Esîr, el-Kâmil, C XI, s. 440.

107 İbnü'l-Cevzî, el-Muntazam, C XVIII, s. 223.

Belleten, Ağustos 2021, Cilt: 85/Say1: 303; 423-461 
Vezir İbnü'l-Müslime ve halifenin arasının neden açıldığına dair farklı bilgiler vermektedir. Bu noktada Sıbt İbnü'l-Cevzî, Sâhibülmahzen İbnü'l-Attâr'ın İbnü'l-Müslime'ye karşı açıkça düşmanlık yaptığını ve Halife Müstazî’nin İbnü’lMüslime hakkındaki düşüncelerini değiştirmesine sebep olduğunu aktarmaktadır. Müstazî’nin kendisiyle ilgili düşüncelerinin değiştiğini fark eden İbnü’l-Müslime de o yll hacca gitmek için halifeden izin istemiştir ${ }^{108}$.

Konuyla ilgili İbnü'l-Gevzî’nin kayıtlarına bakılacak olursa [Bâbülâmme hâcibi] Ebû Mansûr b. el-Âlâ gözaltına alındıktan sonra malları müsadere edilmiş ve bundan dolayı Bağdat'ta büyük bir kargaşa meydana gelmiştir. Söz konusu meselede Vezir İbnü'l-Müslime'nin bir dahlinin olup olmadığına dair bilgi verilmemektedir. Buna rağmen rivayetin devamında yanına herhangi bir kişinin girmesine ve resmî merasimlere katılmasına izin verilmeyen İbnü'l-Müslime'nin mallarının müsadere edilmek istendiği, fakat daha sonra büyük bir kısmının kendisine iade edildiği zikredilmektedir. Ayrıca İbnü'l-Müslime'nin bu duruma düşmesiyle emrinde bulunan divanlarla ilgili işlerin çoğunun Sâhibülmahzen İbnü'l-Attâr'ın uhdesine verildiği aktarılmaktadır (Safer 573/Temmuz-Ağustos $1177)^{109}$. Yaklaşı dört ay sonra tekrar merasimlere katılmasına müsaade edilen İbnü'l-Müslime, Dârülhilâfe'ye giderek başta Sâhibülmahzen İbnü'l-Attâr olmak üzere kendisini tebrik etmeye gelenleri huzuruna kabul etmiştir (16 Cemâziyelâhir 573/10 Aralık 1177) ${ }^{110}$.

Günümüz araştırmacılarından Azzâm, İbnü’l-Attâr'ın etkisinin dışında, Safedî’den naklen İbnü'l-Müslime'nin gözden düşmesinde sert ve zorba bir karaktere sahip olmasıyla tanınan oğlu Üstâdâr Kemâlüddîn'in bir takım tasarruflarının etkili olduğunu iddia etmektedir ${ }^{111}$.

Safedî’nin eserinde Kemâlüddîn’in tabiatı itibariyle çok sert olduğu ve İbnü’lMüslime ailesi içinde onun kadar kötü bir şahıs bulunmadığı şeklinde bazı bilgiler verilmekle birlikte, Azzâm’ın iddia ettiği gibi İbnü'l-Müslime’nin gözden düşmesinde oğlunun bu özelliklerinin etkili olduğuna dair herhangi bir kayıt bulunmamaktadır ${ }^{12}$. Ayrıca daha önce de işaret edildiği üzere İbnü'l-Müslime

108 Sibt İbnü'l-Cevzî, Mir'âtü'z-zamân, C XXI, s. 227.

109 İbnü'l-Cevzî, el-Muntazam, C XVIII, s. 235-236.

110 İbnü'l-Cevzî, el-Muntazam, C XVIII, s. 237.

111 Azzâm, el-Vizâretii'l-Abbâsiyye, s. 184.

112 Safedî, el-Vâfi, C XIX, s. 267. 
birinci vezirliğinden azledilince oğlu Kemâlüddîn de üstâdârlık görevinden ayrılmıştı. Kaynaklarda onun bu göreve bir daha atandığına dair bir bilgi yer almamaktadır. Dolayısıyla bu sırada Kemâlüddîn’in resmî herhangi bir görevi yoktur. Diğer taraftan İbnü'l-Cevzînnin iki farklı bağlamda aktarmış olduğu rivayetlerden hareketle Halife Müstazî'nin emriyle Vezir İbnü'l-Müslime'nin görevlerinden kısmen el çektirildiği anlaşılmaktadır. Fakat bu anlatımlarda Halife Müstazînnin neden böyle bir tedbire başvurduğuna dair kesin bir bilgi bulunmamaktadır. Bununla birlikte İbnü'l-Attâr'nn, (oğlunun yaptıklarından dolayı ?) oluşan olumsuz havayı kullanarak halife nezdinde İbnü'l-Müslime aleyhinde bazı girişimlerde bulunmuş olması muhtemeldir. Bu durum karşısında İbnü'l-Müslime'nin de kendi aleyhindeki bu havayı yumuşatmak ve bir müddet Bağdat'taki siyasî ortamdan uzaklaşmak için hacca gitmeye karar verdiği ve bu amaçla halifeden izin aldığı düşünülebilir.

Müstazî ile arasının açılmasından sonra hac ibadetini yerine getirmek maksadıyla halifeden izin alan İbnü'l-Müslime, Bağdat'tan ayrıldı. Aralarında küçük farklılıklar bulunmakla birlikte İbnü'l-Cevzî ve Sıbt İbnü'l-Cevzî’nin verdikleri bilgilere göre büyük bir hazırlık yapan İbnü'l-Müslime, ulemâ, edipler ve zahidlerden oluşan kalabalık bir grupla birlikte 4 Zilkade 573 (24 Nisan 1178) tarihinde Dicle'nin batı tarafına geçti. Bu sırada halkın büyük bir kısmı kendisine sevgi gösterisinde bulunurken, hizmetçiler, hâcibler ve kâdılkudât gibi kişiler de İbnü'l-Müslime’yi yolcu ediyorlardı. Sâhibülmahzen İbnü'l-Attâr ise uğurlamaya gelmemişti. İbnü'lMüslime ve beraberindekiler Bağdat'ın batı yakasında çarşlarıyla meşhur büyük bir mahalle olan Katûftâ'ya geldiklerinde sûfî görünümlü bir kişi elinde bir mektup olduğunu ve bunu ancak İbnü'l-Müslime’ye vereceğini belirterek görevlilerden kendisini vezirle görüştürmelerini istedi. Bunun üzerine görevliler onu İbnü'lMüslime'nin yanına yaklaştırdılar. Bu sırada üzerinde gizlediği bıçakla İbnü'lMüslime'ye saldıran bu kişi veziri ağır bir şekilde yaraladı. Hâcib İbnü'l-Muavvic ise saldıran kişinin üzerine atlayarak onu öldürdü, ayrıca katille işbirliği yaptığı söylenen iki kişi de bu sırada öldürüldü. Aldığı yaranın etkisiyle atından düşen ve öleceği anlaşılan İbnü'l-Müslime ise hemen evine kaldırıldı. O gün öğleden sonra da vefat etti. Cenazesi Mansûr Camii’nde kılındıktan sonra vasiyeti üzerine caminin yanında bulunan ribâtın haziresine babasının yanına defnedildi ${ }^{113}$.

113 İbnü'l-Cevzî, el-Muntazam, C XVIII, s. 240-241, 246-247; Sıbt İbnü'l-Cevzî, Mir'âtü'z-zamân, C XXI, s. 254-255. Ayrıca bk. İbnü'l-Esîr, el-Kâmil, C XI, s. 446-447; İbnü't-Tıktakâ, el-Fahrî, s. 321; Zehebî, Târîh: sene 571-580, s. 18-19. 
Kaynaklarda İbnü’l-Müslime'nin öldürülmesinin arkasında farklı kişilerin olabileceğine dair bazı rivayetler aktarılmıştır. Sıbt İbnü'l-Gevzî’nin verdiği bilgiye göre öteden beri İbnü'l-Müslime ile aralarında düşmanlık bulunan Emîr Tutâmış, bir bâtınî fedaisiyle anlaşarak veziri öldürtmüştür. İbnü’l-Müslime’nin vefatıyla birlikte Halife Müstazî, Tutâmış'ın gözaltına alınmasını ve mallarına el konulmasını emretmiştir. Anlaşıldı̆̆ı kadarıyla Müstazî’yi böyle bir karar vermeye sevk eden şey, Tutâmış'ın pek çok defa halifeyi hacca gitmesi için teşvik etmesi ve nihayetinde vezirin de hac yolcuğu sirasında öldürülmesidir. Rivayetin sonunda Tutâmış’n, veziri öldüren bâtıninin halifeyi de öldürmesinden korktuğuna işaret edilmesi dikkat çekmektedir ${ }^{114}$. Bu durum Tutâmış'ın halifeyi hacca gitmeye teşvik ederek bu sırada onu bir bâtınî tarafindan öldürtmeyi planladığına işaret ediyor olabilir. Nitekim olaydan sonra halifenin Tutâmış'ı gözaltına alması bu ihtimali güçlendirmektedir.

Konuyla ilgili yine Sıbt İbnü'l-Gevzî’nin babası Hüsâmüddîn'den naklen aktardığına göre, o sırada İbnü'l-Attâr'ın yanında bulunan Hüsâmüddîn, İbnü'lAttâr'ın çok endişeli olduğunu ve İbnü'l-Müslime'nin öldürüldüğunü duyunca sevincinden bağırarak tekbir getirdiğini söylemektedir. Rivayetin devamında İbnü'l-Attâr'ın ayrıca, İbnü'l-Müslime'nin üstâdârlık yaptığı dönemde İbn Hübeyre'nin öldürülen iki oğlu İzzüddîn Ebû Abdullah ve Şerefüddîn Zafer'in böylece intikamının alındığını söylediği nakledilmektedir ${ }^{115}$.

Önceki anlatımlara bakıldığında İbnü'l-Müslime'nin öldürülmesinde Emîr Tutâmış veya İbnü'l-Attâr'dan hangisinin rolü olduğuna dair kesin bir hüküm vermek pek mümkün görünmemektedir. Bununla birlikte İbnü’l-Cevzî’nin kayıtlarında bu işi her ikisinin birlikte planladığına dair bazı imaların bulunduğu anlaşılmaktadır. Şöyle ki, vezirin öldüğü günün akşamında İbnü'l-Attâr, her zaman yaptığı gibi kendisiyle görüşmek üzere Tutâmış’ evine çağırmış, ancak gelir gelmez onu tutuklatmış ve elinde bulunan mallara el koymuştur. Bazı kişiler ise İbnü'lAttâr ve Tutâmış'ı kastederek veziri öldürmek üzere bir bâtınî ile anlaştıklarını söylemişlerdir ${ }^{116}$. Bu noktada İbnü'l-Müslime ile araları bozulan İbnü'l-Attâr'ın vezirin aleyhinde Tutâmış'la işbirliği yaptığı, Tutâmış’ın ise İbnü'l-Müslime'nin en büyük düşmanı olan kayınbiraderi Kaymâz’n intikamını almak için İbnü'lAttâr'la birlikte hareket ettiği söylenebilir.

114 Sibt İbnü'l-Cevzî, Mir'âtü'z-zamân, C XXI, s. 255.

115 Sıbt İbnü'l-Cevzî, Mir'âtü'z-zamân, C XXI, s. 255.

116 İbnü'l-Cevzî, el-Muntazam, C XVIII, s. 241. 


\section{Sonuç}

Beş asırdan daha uzun bir süre tarih sahnesinde kalan Abbâsîler yaklaşık iki asır boyunca önce Irak Büveyhîleri'nin ardından Selçuklular'ın (Büyük Selçuklular ve Irak Selçukluları) nüfuzu altında varlıklarını devam ettirmişlerdir. Selçuklu nüfuzunun büyük oranda etkisini yitirdiği VI. (XII.) asrın ortalarından itibaren siyasî ve ekonomik açıdan olduğu kadar idarî açıdan da önemli değişimler yaşanmıştır. Bu süreçte başta vezir olmak üzere devlet kademesindeki üst düzey kişiler giderek etkinliklerini arttırmıslar ve bunun sonucunda birbirleriyle kıyasıya bir güç mücadelesine girişmişlerdir. Özellikle bazı halifelerin idarî açıdan nispeten yetersiz olmaları, bu mücadelelerin şiddetini daha da arttırmıştır.

Abbâsîler'de Selçuklu nüfuzunun sona ermesi için büyük bir çaba sarfeden ve siyasî ve askerî faaliyetleri bakımından seleflerine nazaran daha ön plana çıkan Vezir İbn Hübeyre özellikle malî sahalarla ilgili aldığı bazı kararlardan dolayı toplumda bir takım rahatsızlıklara neden olmuştur. Esasen İbn Hübeyre'nin bu tarz kararlar almasındaki en önemli etken Selçuklu hakimiyetinden çıkış sürecinde devletin içinde bulunduğu ekonomik sıkıntılardır. Zira uzun yıllardır Irak'ın verimli arazilerinden elde edilen gelirlerin Selçuklu devlet adamlarına ve komutanlarına tahsis edilmesi Abbâsîler’i büyük bir malî krize sürüklemiştir. Bir vezir olarak Vezir İbn Hübeyre de devleti içinde bulunduğu bu malî sıkıntıdan kurtarmak için iktâ arazilerinin statüsünü haracî araziye çevirerek hazinenin daha fazla gelir elde etmesini amaçlamıştır. Ancak bu karar, hemen hemen toplumun bütün kesimlerinde büyük bir tedirginliğe neden olmuştur.

Yürürlüğü koyduğu uygulamalarla toplumda tepki çeken Vezir İbn Hübeyre zehirlenme sonucu ölmüştür. Ancak kaynaklarda onun kim tarafindan ve hangi sebeple zehirlendiği hususunda açık bir bilgi mevcut değildir. Bu noktada bazı araştırmacılar İbn Hübeyre'nin zehirlenmesiyle sonuçlanan olayları mezhebî saiklerle izah etme iddiasındadır. Buna göre İbn Hübeyre, Hanbelî mezhebini bir baskı unsuru olarak kullandığı için Üstâdâr İbnü'l-Müslime bu durumdan rahatsız olan Bağdat'ın sermaye sahibi önde gelen ailelerinin doğal lideri haline gelmiştir. Yine bu meseleyle irtibatlı olarak Halife Müstencid denge unsuru oluşturmak için Vezir İbn Hübeyre'ye karşı İbnü'l-Müslime'yi desteklemiştir. Esasen İbn Hübeyre'nin yaşadığı dönemde Hanbelî mezhebinin nispeten etkili olduğu doğrudur. Ancak tespit edebildiğimiz kadarıyla İbnü'l-Müslime'nin bu durumdan rahatsız olan zümrelerin doğal lideri haline geldiğini ve halifenin İbn Hübeyre'ye karşı dengeyi sağlamak için İbnü’l-Müslime’yi desteklediğini gösteren net bir veri 
bulunmamaktadır. Aynı şekilde İbn Hübeyre'nin Hanbelî mezhebini öne çıkaran uygulamarının toplumda rahatsızlık meydana getirdiğini gösteren bir rivayet de söz konusu değildir. Ancak dönemin müellifi İbnü’l-Gevzî toplumda huzursuzluğa neden olan uygulamanın İbn Hübeyre tarafindan iktâ arazilerinin haracî araziye dönüştürülmesi olduğunu açı bir şekilde kaydetmektedir. Dolayisıyla toplumun diğer fertleri gibi sermaye sahibi ailelerin de mezhebî kaygılardan ziyade Vezir İbn Hübeyre'nin aldığı kararlar sebebiyle ekonomik açıdan zor durumda kaldığı ve bundan dolayı toplumda bir huzursuzluğun yaşandığı anlaşılmaktadır. Ancak buna rağmen mevcut rivayetlerden hareketle İbnü'l-Müslime'nin söz konusu ailelerin lideri haline geldiğini söylemek mümkün değildir. Dahası İbnü'lMüslime'nin nüfuzunu arttıran husus mezhebî faktörlerden ziyade onun bizatihi üstâdârlık kurumunun başında olmasıdır. Zira üstâdâr olarak görev yapan kişiler uzun zamandır Abbâsî idaresinde etkin bir konuma sahip olmuşlar ve bundan dolayı vezirliğe atanması muhtemel en güçlü şahıslar olarak öne çıkmışlardır.

Vezir İbn Hübeyre ile Üstâdâr İbnü'l-Müslime arasındaki ilişkiyle ilgili dile getirilen bir başka iddia, İbn Hübeyre'nin zehirlenerek ani ve şüpheli ölümünün arkasinda İbnü'l-Müslime'nin bulunduğudur. Ancak İbn Hübeyre'nin zehirlenme sonucunda öldüğü kaynakların büyük çoğunluğu tarafindan dile getirilmekteyse de bu işin arkasında kimin bulunduğuna dair herhangi bir bilgi verilmemektedir. Dolayısıyla kuvvetli bir delil ortaya koymaksızın sadece aralarındaki çekişmeden hareketle bu konuda İbnü’l-Müslime'nin rolünün bulunduğunu iddia etmek biraz kolaycı bir yaklaşım olacaktır.

İbnü'l-Müslime'nin Abbâsî idaresindeki nüfuzunu arttırması başta Halife Müstencid olmak üzere siyasî güç sahipleriyle arasındaki ayrılığın daha da derinleşmesine yol açmıştır. Bu noktada Halife Müstencid'in mevcut şartlarda İbnü'l-Müslime'nin gücünü azaltmaya yönelik attığı adımlar kendi sonunu getirdiği gibi İbnü’l-Müslime'nin etkinliğini bir adım daha ileriye götürmesini sağlamıştır. Nitekim dönemin etkili şahsiyetlerinden Emîr Kaymâz'la ittifak kuran İbnü'l-Müslime, Müstencid'i ortadan kaldırarak yerine Müstâzî̀yi tahta çıarmıştır. Müstâzî de iktidarını kendilerine borçlu olduğu İbnü'l-Müslime'yi vezirliğe, oğlu Kutbuddîn'i üstâdârlığa, Emîr Kaymâz’ı da ordu komutanlığına atamıştır. Ancak Müstencid sonrası iktidarı birlikte planlamalarına rağmen aralarındaki güç mücadelesi İ̉nü'l-Müslime'nin Emîr Kutbuddîn Kaymâz ve Emîr Tutâmış'la arasının açılmasına neden olmuştur. Her ne kadar İbnü’l- 
Müslime bu düşmanlarından bir kısmını bertaraf etmeyi başarmış gibi görünse de sonuçta kimliği belirsiz bir kişinin saldırısı sonucu ölmüştür.

Netice itibariyle VI. (XII.) asrın sonlarına gelindiğinde devletin üst kademesindeki kişilerin birbiriyle mücadelesinde zaman zaman kendi otoritesini koruyamayan halifelerin iş başına gelmesi ve bir taraf olarak bu çekişmelerin içinde yer alması devletin yıkılışına kadar devam edecek bir sürecin de başlangıcını oluşturmuştur. Dahası bu durum Selçuklu nüfuzu sonrası merkezî Irak topraklarında yeniden hakimiyet kuran Abbâsîler'in idarî açıdan ciddî bir zaafiyete uğramasına neden olmuştur. Bu anlamılla aslında Adudüddîn İbnü’l-Müslime'nin içinde bulunduğu ortam, siyasî ve idarî açıdan gerçekleştirdiği faaliyetler, üst düzey devlet adamlarıyla kurduğu ilişkiler ve rakiplerine karşı giriştiği mücadeleler Abbâsîler’in geç dönemi açısından temsil kaabiliyeti yüksek bir örnek olarak karşımıza çıkmaktadır. Bir başka ifadeyle idarenin başlıca unsuru sayllan halife, vezir, üstâdâr, ordu komutanı ve kısmen sâhibülmahzen arasındaki çekişmeler bu görevlere getirilen şahıslar değişmiş olsa bile, devletin yıkılışına kadar yaşanmaya devam etmiştir. 


\section{KAYNAKLAR}

Atalar, Münir, "Emîr-i Hac", İslâm Ansiklopedisi, C 11, Türkiye Diyanet Vakfi, İstanbul 1995, s. 131-133.

Ayaz, Fatih Yahya, "Üstâdüddâr", İslam Ansiklopedisi, G 42, Türkiye Diyanet Vakfi, İstanbul 2012, s. 393-395.

Ayaz, Fatih Yahya, "Vezir", İslam Ansiklopedisi, C 43, Türkiye Diyanet Vakfi, İstanbul 2013, s. 79-82.

Aykaç, Mehmet, “İbn Hübeyre, Ebü’l-Muzaffer”, İslâm Ansiklopedisi, C 20, Türkiye Diyanet Vakfi, İstanbul 1999, s. 82-83.

Azzâm, Subhî Mahmûd, el-Vizâretii'l-Abbâsiyye (h. 447-656/m. 1055-1258) (doktora tezi), el-Câmi'atü'l-Ürdüniyye, Külliyyetü'd-Dirâsâti'l-'Ulyâ, Amman 2000.

Bâşâ, Hasan, el-Fünûnu'l-İslâmiyye ve'l-vezâif ale'l-âsâri'l-Arabiyye, I-III, Dârü'nNehdati'l-Arabiyye, Kahire 1965.

Bozkurt, Nebi, "Kıyafet", İlâm Ansiklopedisi, C 25, Türkiye Diyanet Vakfi, İstanbul 2002, s. $508-510$.

Buzpınar, Ş. Tufan, "Nakîbüleşrâf", İslâm Ansiklopedisi, C 32, Türkiye Diyanet Vakfi, İstanbul 2006, s. 322-324.

Cahen, Claude, "Ibn al-Muslima", The Encyclopaedia of Islam New Edition, C 3, Brill, Leiden 1986, s. 891-892.

Dûrî, Abdülazîz, "Divan", İslâm Ansiklopedisi, G 9, Türkiye Diyanet Vakfi, İstanbul 1994, s. 377-381.

Dündar, Abdulhamit, 4/10. Yüzynlda Bağdat (Topografya, Toplumsal Yapr, Gündelik Hayat) (doktora tezi), Şeyh Edebali Üniversitesi, Sosyal Bilimler Enstitüsü, Bilecik 2019.

Erbilî, Abdurrahman b. İbrahim b. Sunbut, Hulâsatii'z-zehebi'l-mesbûk muhtasar min Siyeri'l-mülûk (nşr. Mekkî es-Seyyid Câsim), Mektebetü'l-Müsennâ, Bağdat [ts.].

Genç, Süleyman, Fatımî-Abbâsî Selçuklu Münasebetleri (doktora tezi), Dokuz Eylül Üniversitesi, Sosyal Bilimler Enstitüsü, İzmir 1995.

Göl, Yavuz Selim, Abbâsîler Döneminde Kâdı'l-kudâtlık (doktora tezi), Necmettin Erbakan Üniversitesi, Sosyal Bilimler Enstitüsü, Konya 2018. 
Hançabay, Halil İbrahim, Abbâsîler Döneminde Vezirlik (295-530/908-1136), Klasik Yayınları, İstanbul 2017.

Hançabay, Halil İbrahim, "Abbâsîler'in Son Dönem Vezirlerinden Ebü'l-Muzaffer Yahya b. Hübeyre (ö. 560/1165)", Marmara Üniversitesi İlahiyat Fakültesi Dergisi, 53 (2017), s. 45-72.

Hanne, Eric, The Caliphate Revisited: The Abbasids of $11^{\text {th }}$ and $12^{\text {th }}$ Century Baghdad (doktora tezi), The University of Michigan, Near Eastern Studies, Michigan 1998.

Hanne, Eric, "The Banū Jahīr and Their Role in the Abbāsid and Saljuq Administrations", Al-Masaq: Islam and Medieval Mediterranean, 20 (2008), s. 2945.

Hofer, Nathan, "The Origins and Development of the Office of the "Chief Sufi" in Egypt, 1173-1325", Fournal of Sufi Studies, 3 (2014), s. 1-37.

İbn Hallikân, Ebü'l-Abbâs Şemsüddîn Ahmed b. Muhammed, Vefeyâtu'l-'ayân ve enbâü ebnâi'z-zamân (nşr. İhsan Abbâs), I-VIII, Dâru Sâdır, Beyrut 1398/1978.

İbn Miskeveyh, Ebû Alî Ahmed b. Muhammed, Kitâbiu Tecâribi'l-Ümem (nşr. Henry Frederick Amedroz \& David Samuel Margoliouth), I-II, Matba'atü'şŞeriketi't-Temeddün, Kahire 1914.

İbn Receb, Zeynüddîn Ebü’l-Ferec Abdurrahman b. Şihâbüddîn Ahmed, ez-Zeyl 'alâ Tabakâti'l-Hanâbile, I-II, Dârü'l-Ma'rife, Beyrut [ts.]

İbn Vâsl, Gemâlüddîn Muhammed b. Sâlim, Müferriciu'l-kürûb fì ahbârî mülûki Benî Eyyûb (nşr. Cemâleddin eş-Şeyyâl), I-III, Kahire 1953-60.

İbnü'l-Gevzî, Ebü'l-Ferec Cemâlüddîn Abdurrahman b. Alî b. Muhammed elBağdâdî, el-Muntazam fî târîhi'l-mülûk ve'l-ümem (nşr. Muhammed Abdülkadir Atâ \& Mustafa Abdülkadir Atâ), I-XIX, Dârü'l-Kütübi'l-İlmiyye, Beyrut $1412 / 1992$.

İbnü'd-Dübeysî, Ebû Abdullah Cemâlüddîn Muhammed b. Saîd, Zeylü Târîhi Medîneti's-selâm (nşr. Beşşâr Avvâd Ma'rûf), I-V, Dârü'l-Garbi'l-İ̀lâmî, Beyrut $1427 / 2006$.

İbnü'l-Esîr, Ebü'l-Hasen İzzüddîn Alî b. Muhammed, el-Kâmil fi't-târîh (nşr. Carl Joan Tornberg), I-XII, Dâru Sâdır \& Dâru Beyrut, Beyrut 1965. 
İbnü't-Tiktakâ, Ebû Ca'fer Safiyyüddîn Muhammed b. Alî b. Tabatabâ, el-Fahn̂ fi'l-âdâbi's-sultâniyye ve'd-dïveli'l-İslâmiyye, Dâru Sâdır, Beyrut [ts.].

İlhan, Avni, "Atebât", İslâm Ansiklopedisi, C 4, Türkiye Diyanet Vakfi, İstanbul 1991, s. 49-50.

İmâdüddîn el-İsfahânî, Ebû Abdullah, Muhammed b. Muhammed, Harîdetül'-kasr ve cerîdetiì'l-asr: el-kısmü'l-Irâkî, (nşr. Muhammed Behçet el-Eserî \& Cemîl Saîd), I-V, Matba'atü Mecma'i'l-İlmî el-Irâk $\hat{\imath}$, Bağdat 1955-1964.

Kabir, Mafizullah, The Buwayhid Dynasty of Baghdad (334/946-447/1055), Iran Society, Calcutta 1964.

Kızlltoprak, Süleyman, "Memlük", İslâm Ansiklopedisi, G 28, Türkiye Diyanet Vakfi, İstanbul 2004, s. 87-90.

Köprülü, Fuat, "Arz", İslâm Ansiklopedisi, G 1, Milli Eğitim Bakanlığı, İstanbul 1978, s. 657-660.

Kucur, Sadi S., “İbnü'l-Müslime, Adudüddin”, İslâm Ansiklopedisi, C 21, Türkiye Diyanet Vakfi, İstanbul 2000, s. 160-161.

Kütübî, Muhammed b. Şâkir, el-Fevâtü'l-Vefeyât ve'z-zeyl 'aleyhâ (nşr. İhsan Abbas), I-V, Beyrut 1973-1974.

Mackay, P. A., "Patronage and Power in 6th/12th Century Baghdad. The Life of the Vizier 'Adud al-Dīn Ibn Al-Muzaffar", Studia Islamica, 34 (1971), s. 27-56.

Mason, Herbert, Two Statesmen of Medieval Islam: Vizir Ibn Hubayra and Caliph anNâsir li Dîn Allâh, Mouton Publishers, Netherlands 1972.

Merçil, Erdoğan, "Selçuklular (Selçuklular'da Devlet ve Teşkilat)", İslâm Ansiklopedisi, C 36, Türkiye Diyanet Vakfi, İstanbul 2009, s. 389-392.

Merçil, Erdoğan, "Ârız”, İslâm Ansiklopedisi, G 3, Türkiye Diyanet Vakfi, İstanbul 1991, s. 359.

Mukâbele, Ma'an Alî Ahmed, İhyâu'l-hilâfeti'l-Abbâsiyye fi'l-fetra min "530-622 h./1135-1225 m." (doktora tezi), el-Câmi'atü'l-Ürdüniyye, Külliyyetü'dDirâsâti'l-'Ulyâ, Amman 1999.

Öz, Mustafa, "Meşhed”, İslâm Ansiklopedisi, C 29, Türkiye Diyanet Vakfi, İstanbul 2004, s. 362-363. 
Özaydın, Abdülkerim, "Selçuklular Döneminde Nakîbü’n-Nukabâların Siyâsî, İdârî ve İçtimâî Hayattaki Rolleri: Tırâd b. Muhammed ve Oğlu Alî b. Tırâd el-Kureşî el-Hâşimî el-Abbâsî ez-Zeynebî Örneği”, Türkiye Yazarlar Birlĭgi (TYB) Akademi: Dil Edebiyat ve Sosyal Bilimler Dergisi, 12 (2014), s. 101-114.

Özaydın, Abdülkerim, "Benî Gehîr", İslâm Ansiklopedisi, C 5, Türkiye Diyanet Vakfi, İstanbul 1992, s. 447-449.

Sâbî, Ebü'l-Hüseyin Hilâl b. Muhassin, Rüsûmü dâri'l-hilâfe (nşr. Mîhâîl Avvâd), Dârü'r-Râidi'l-Arabî, Beyrut 1406/1986.

Saâ‘de, Safiyye, Tatavouru mansibi'l-kâdi'l-kudât fi'l-fetreteyn el-Büveyhiyye ve's-Selcûkiyye, Dâru Emvâc, Beyrut 1988.

Safedî, Selâhuddîn Halîl b. Aybeg, el-Vâfi bìl-vefeyât (nşr. Ahmed el-Arnaûd \& Türkî Mustafa), I-XIX, Dâru İhyâi't-Türâsi'l-Arabî, Beyrut 1420/2000.

Sıbt İbnü'l-Gevzî, Ebü'l-Muzaffer Şemsüddîn Yûsuf b. Kızoğlu, Mir'âtiu'z-zamân fî tevârîhi'l-a'yân (nşr. Muhammed Berakât-vd), I-XXIII, er-Risâletü'l-Âlemiyye, Dımaşk 1434/2013.

Sıbt İbnü't-Teâvîzî, Ebü'l-Feth Muhammed b. Ubeydillâh, Divoân (nşr. David Samuel Margoliouth), Matba'atu'l-Muktataf, Kahire 1903.

Şeşen, Ramazan, "Dârülhilâfe", İslam Ansiklopedisi, C 8, Türkiye Diyanet Vakfi, İstanbul 1993, 538-539.

Şükürov, Qıyas, "Şümle", İslâm Ansiklopedisi, C Ek-2, Türkiye Diyanet Vakfi, İstanbul 2019, s. 565-566.

Taneri, Aydın, "Hâcib", İslâm Ansiklopedisi, C 14, Türkiye Diyanet Vakfi, İstanbul 1996, s. 508-511.

Taneri, Aydın, "Divan (Büyük Selçuklular'da Divan)", İslâm Ansiklopedisi, C 9, Türkiye Diyanet Vakfi, İstanbul 1994; s. 383-385.

Ubeydî, Salâh Hüseyin, el-Melâbisï'l-'Arabiyyetii'l-İslâmiyye fi'l-Asri'l-'Abbâsî, Dârü'rReşî̀d li’n-Neşr, Bağdat 1980.

Yâkût b. Abdullah el-Hamevî, Mu'cemǘl-buildân, I-V, Dâru Sâdır, Beyrut 1397/1977.

Yılmaz, Harun. "Meşîhatüşşüyûh'un Doğuşu ve Mısır'da İki Hankah: Sa‘îdü'sSü'adâ ve Siryâkûs", Tasavouf İlmî ve Akademik Araşttrma Dergisi, 34 (2014), s. $1-21$. 
Yılmaz, Harun, "Şeyhüşsüyûh", İslâm Ansiklopedisi, C Ek-2, Türkiye Diyanet Vakfi, İstanbul 2019, s. 562-563.

Yılmaz, Saim, "Abbâsîler'de Üstâdârlık Müessesesinin Ortaya Çıkışı", İslâm Araştrmalan Dergisi, 21 (2009), s. 1-24.

Yılmaz, Saim, "Abbâsîler Dönemi Türk Komutanlarından Mûnis el-Muzaffer'in (ö. 321/933) Hayatı ve Askerî Görevleri”, Çukurova Üniversitesi İlahiyat Fakültesi Dergisi, 7 (2007), s. 123-156.

Yılmaz, Saim, “Türk Komutanlardan Mûnis el-Muzaffer'in (ö. 321/933) Abbâsî Tarihindeki Siyasî Etkinliği”, Dinî Araştırmalar, 30 (2008), s. 121-152.

Yiğit, İsmail, "Ribât", İslâm Ansiklopedisi, C 35, Türkiye Diyanet Vakfi, İstanbul 2008, s. 76-79.

Yılmaz, Saim - Sazak, Ömer, "Doğu Bağdat'ta Dârülhilâfe'nin Ortaya Çıkışı ve Burada İnşa Edilen Saraylar (279-334/892-945)", Sakarya Üniversitesi İlahiyat Fakültesi Dergisi, 42 (2020), s. 285-313.

Zehebî, Ebû Abdullah Şemsüddîn Muhammed b. Ahmed b. Osmân, elMuhtasarï'l-muhtâc ileyhi min Târîhi İbni'd-Dübeysî (nşr. Mustafa Cevâd), I-III, Matba'atü'z-Zamân, Bağdat 1951-1977.

Zehebî, Ebû Abdullah Şemsüddîn Muhammed b. Ahmed b. Osmân, Siyeru a'lâmi’n-nübelâ' (nşr. Şuayb el-Arnaût-vd.), I-XXV,: Müessesetü'r-Risâle, Beyrut 1403/1983.

Zehebî, Ebû Abdullah Şemsüddîn Muhammed b. Ahmed b. Osmân, Târîhu'l-İslâm ve vefeyâtii'l-meşâhir ve'l'alâm: sene 551-560 (nş̧r. Ömer Abdüsselâm Tedmürî), Dârü'l-Kütübi'l-Arabî, Beyrut 1411-1421/1991-2000. 


\section{EK}

İbnü'l-Müslime ailesinin soy ağac1 ${ }^{117}$

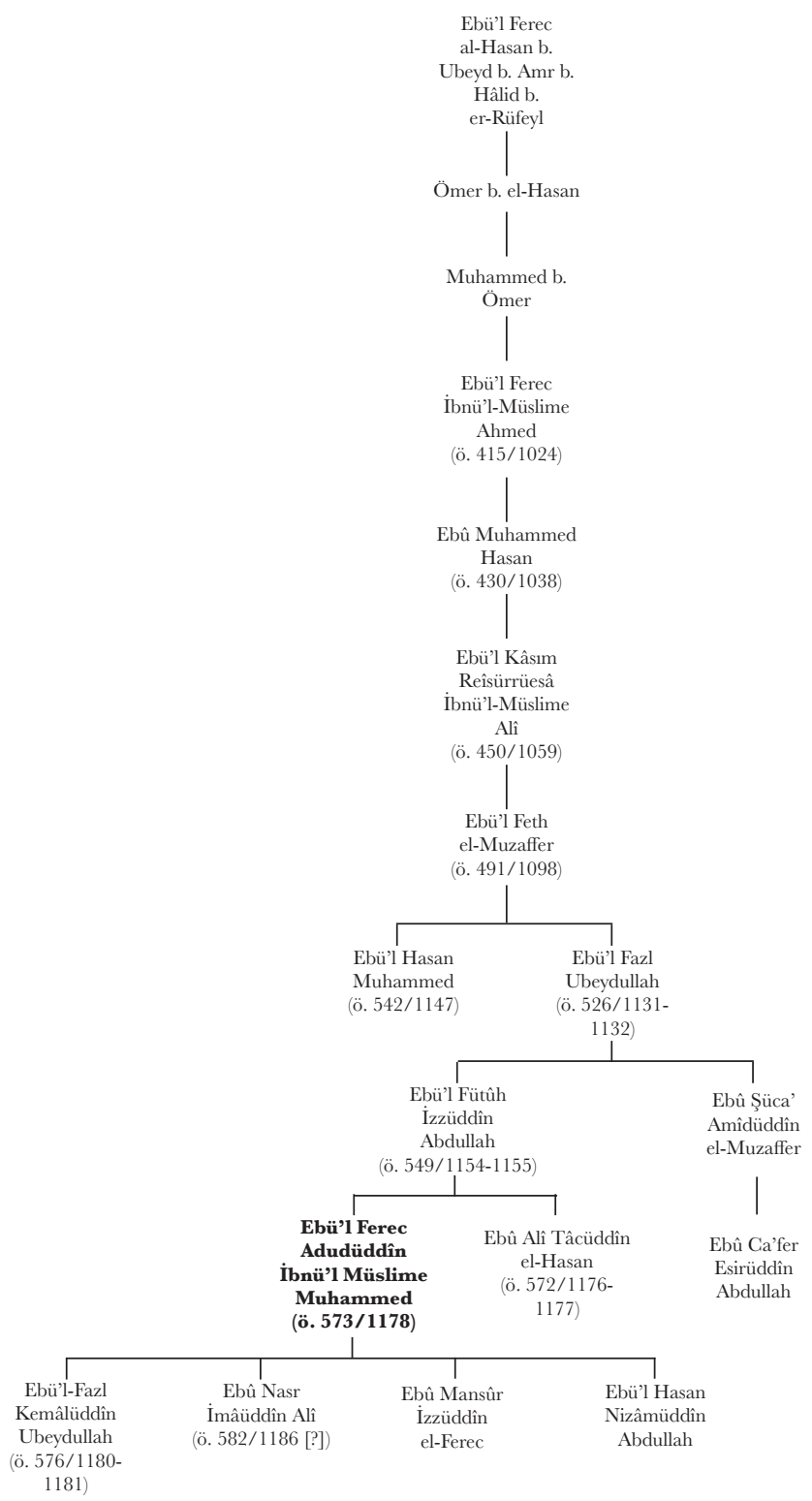

117 Soy ağacıyla ilgili bazı bilgiler için bk. Mackay, "Patronage and Power", s. 56.

Belleten, Ağustos 2021, Cilt: 85/Sayı: 303; 423-461 